\title{
INHERITANCE IN HYDATINA SENTA
}

\section{VIABILITY OF THE RESTING EgGS AND THE SEX RATIO}

\author{
A. FRANKLIN SHULL
}

The Department of Zoölogy, University of Michigan

TWO FIGURES

CONTENTS

Introduction...................................... 49

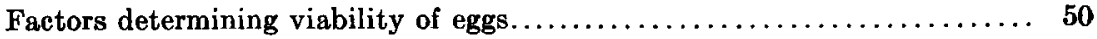

General account of the experiments......................... 52

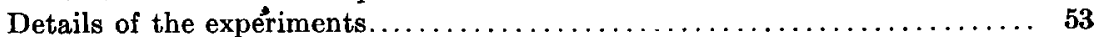

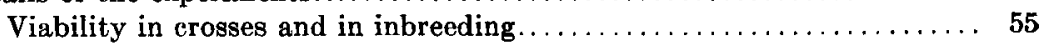

Effect of selection for low viability in a hybrid line............... 65

Effect of selection for high viability in a hybrid line.............. 69

Effect of crossing on viability in two lines made different by selection.. 72

Effect of selection for high and low viability in the low viability series (repeatedly inbred).................................

Effect of selection for high and low viability in the high viability series (repeatedly inbred) $\ldots \ldots \ldots \ldots \ldots \ldots \ldots \ldots \ldots \ldots \ldots \ldots \ldots$

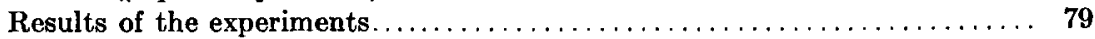

Interpretation of results. $\ldots \ldots \ldots \ldots \ldots \ldots \ldots \ldots \ldots \ldots \ldots \ldots \ldots \ldots \ldots \ldots, 83$

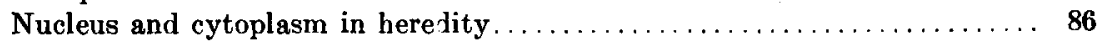

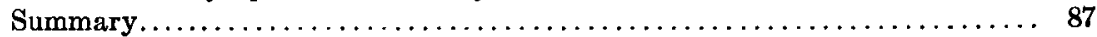

Bibliography $\ldots \ldots \ldots \ldots \ldots \ldots \ldots \ldots \ldots \ldots \ldots \ldots \ldots \ldots \ldots \ldots \ldots \ldots$

\section{INTRODUCTION}

Several years ago in an attempt to effect crosses between parthenogenetic lines of the rotifer Hydatina senta, it was found that the proportion of fertilized eggs that would hatch varied greatly in different lines. In one cross, only one egg in several hundred hatched, although the batch of eggs was kept for weeks; in another, about one-eighth of the whole lot hatched. Since then crosses have been made which resulted in a much higher proportion of viable eggs, up to more than 50 per cent of viability.

${ }^{1}$ Contribution from the Zoölogical Laboratory of the University of Michigan. 
The same condition was found among inbred eggs. Females fertilized by. males of their own parthenogenetic line laid eggs which, in some lines, did not hatch at all, though the eggs were kept for many weeks, and though some of them were dried, others frozen-treatment generally supposed to favor the hatching of such eggs. Of other lots of inbred eggs, 50 to 70 per cent were viable.

In the autumn of 1911 I obtained particularly favorable material with which to test the possible inheritance of this viability of the fertilized eggs. Two lines were found, one of which produced highly viable fertilized eggs by inbreeding, the other only slightly viable. The experiments about to be described show this viability to be a rather definitely inherited character. 'Its behavior in inbreeding, in crosses, and in selection have been tested, and some results of theoretical interest beyond the limits of this particular problem obtained.

I take pleasure in acknowledging the invaluable assistance of Miss Frances J. Dunbar in carrying the experiments over critical periods during my enforced absence.

\section{FACTORS DETERMINING VIABILITY OF EGGS}

The following are some of the factors that seem to me to govern the proportion of eggs that hatch:

1. A solvent which reduces the thickness of the chitinous shell of the egg is apparently produced. The effect of this solvent is perceptible in parthenogenetic eggs shortly before hatching, when the shell, thinner at some points than at others, yields to pressure from within, and is raised in visible humps. When the embryo has emerged, the shell is plainly very much thinner than the shell of a freshly laid egg from which the egg itself has been crushed by pressure. In fertilized eggs this solvent does not usually produce any visible effect, for the young rotifer breaks out while the shell is still quite thick. It is ordinarily quite difficult to distinguish an empty shell from an unhatched fertilized egg, unless the break in the chitin can be seen. Sometimes, however, the embryo does not break from the shell until the latter is quite thin and transparent. These occasional cases show that such a solvent exists. Variations in the production 
of this solvent may account for differences in viability in different lots of eggs.

2. Muscular power of the embryo probably determines the hatching in part. Shells that have been made quite thin by the solvent sometimes remain unbroken, owing to weakness of the young rotifers.

3. Some of the eggs classed as fertilized may not really be fertilized, and so incapable of development, or else incapable of producing an embryo that can escape from the shell. Several years ago I obtained, by mating a female with an old male, a family consisting in part of fertilized eggs, in part of male eggs. This is the only case of the kind ever recorded. The fertilized eggs were laid first, and one of them hatched, producing a female. They were followed by a number of smaller eggs, all of which had shells somewhat thicker than parthenogenetic eggs usually have, but not so thick as fertilized eggs. Some of these small eggs hatched, though the embryo remained in the egg stage longer than the usual twelve to fourteen hours common to parthenogenetic eggs. A number of the small eggs did not hatch, which is uncommon in parthenogenetic eggs. I believe this failure to hatch in some, and delay in hatching in others, to be due to the thicker shells. In some way impregnation of the female seemed to stimulate the production of thicker shells, even on the eggs that were not fertilized. May this not be the case frequently? Small eggs, sometimes not any larger than male eggs, were not uncommonly found in these experiments; but they had thick shells bearing the usual pilose projections, and were classed as fertilized eggs. If these were unfertilized, anything that caused a variation in the number of them produced might affect the proportion of eggs that hatched.

4. Environmental conditions no doubt play an important rôle in the hatching of the fertilized eggs. There are plain indications that this is the case, though in what way or to what extent has been only partially worked out.

Which, if any, of the first three of these factors is responsible for the variations in the viability of the eggs that were the subject of these experiments is not known. 


\section{GENERAL ACCOUNT OF THE EXPERIMENTS}

The diagram in figure 1, with the following description, will make clear the nature of the whole series of experiments. The parthenogenetic lines used were derived originally from rotifers collected in Grantwood, New Jersey, one in March, the other in May, 1911. These lines were designated $A$ and $B$, respectively, in a former paper. Females of line $A$ were inbred with males of the same line, and from one of the fertilized eggs a new line was started; this line is designated $C$. Females of line $A$ were mated with males of line $B$, and from one of the fertilized eggs a second parthenogenetic line was started; this line is designated $D$ in the diagram.

Lines $C$ and $D$ were each inbred $(C \times C$ and $D \times D)$, and reciprocal crosses between them were obtained $(C \times D$ and $D \times C)$. In these crosses the female parent is named first. The inbred eggs were discarded after determining how many of them would hatch, but from each of the reciprocal crosses a new parthenogenetic line was derived. Throughout the diagram, a batch of eggs and the parthenogenetic line or lines derived from one or more of them are regarded as a unit, since all individuals between one fertilization and the next are believed to have the same genotypic constitution, and are included in one rectangle of the diagram.

The two reciprocal crosses $(C \times D$ and $D \times C)$ were each inbred $[(C \times D) \times(C \times D)$ and $(D \times C) \times(D \times C)]$, and reciprocal crosses $[(C \times D) \times(D \times C)$ and $(D \times C) \times(C \times D)]$ also obtained. Three of these were discarded after determining the viability of the fertilized eggs. The fourth, the inbred $(C \times D) \times(C \times D)$ was continued as two parthenogenetic lines, one started from a family of eggs showing low viability, the other from a family showing high viability of the eggs.

Each of these two lines was inbred, and from the fertilized eggs two parthenogenetic lines started. The line from the low viability line was started from an egg in a family that hatched few of its eggs $\left(L_{1}\right)$; that from the high viability line was derived from an egg in a highly viable family $\left(H_{1}\right)$. These two lines were again inbred. Fertilized eggs were again selected from 
families showing low and high viability, respectively, and from them the lines designated $L_{2}$ and $H_{2}$ were reared.

Each of these lines was inbred, and the fertilized eggs designated $L_{3}$ and $H_{3}$ were secured. $L_{2}$ and $H_{2}$ were also crossed reciprocally $\left(L_{2} \times H_{2}\right.$ and $\left.H_{2} \times L_{2}\right)$, but no parthenogenetic lines were reared in these cases; viability was determined and the eggs discarded.

From this point the low viability and the high viability series may be followed separately. The line bred from the eggs named $L_{3}$ was again inbred, the eggs being marked $L_{4}$. Two families of these eggs were selected, one for low, the other for relatively high viability. From each was reared a new line, each of which was inbred to produce a batch of fertilized eggs ( $L$ from $L$, and $H$ from $L$ ). With these eggs the experiments with the low viability series terminated.

Of the lot of eggs in $H_{3}$, two families were selected, one showing relatively low, the other high viability; from each a line was started. These parthenogenetic lines were inbred to produce the lots of eggs called $L_{1}$ from $H$, and $H_{1}$ from $H$. Selection of families for low and high viability, respectively, was made in these lots of eggs and a parthenogenetic line bred from each. These lines were in turn inbred, the fertilized eggs being designated $L_{2}$ from $H$, and $H_{2}$ from $H$. With these eggs the experiments in the high viability series terminated.

\section{DETAILS OF THE EXPERIMENTS}

The following account of the individual experiments is divided and labeled in accordance with the diagram in figure 1, in connection with which the description may be easily followed.

$A$. The data for this line were published in part in a former paper. It comprised 55.2 per cent of male-producers.

$B$. This line was likewise given in an earlier publication. It included 16.5 per cent of male-producers.

$C$. The resting eggs of this lot were obtained by mating females with males of line $A$ on June 28 and 29, 1911. These females laid on the average $8 \mathrm{eggs}$ apiece. The eggs were dried soon after laying, and remained in this condition until August 31, 1911, 


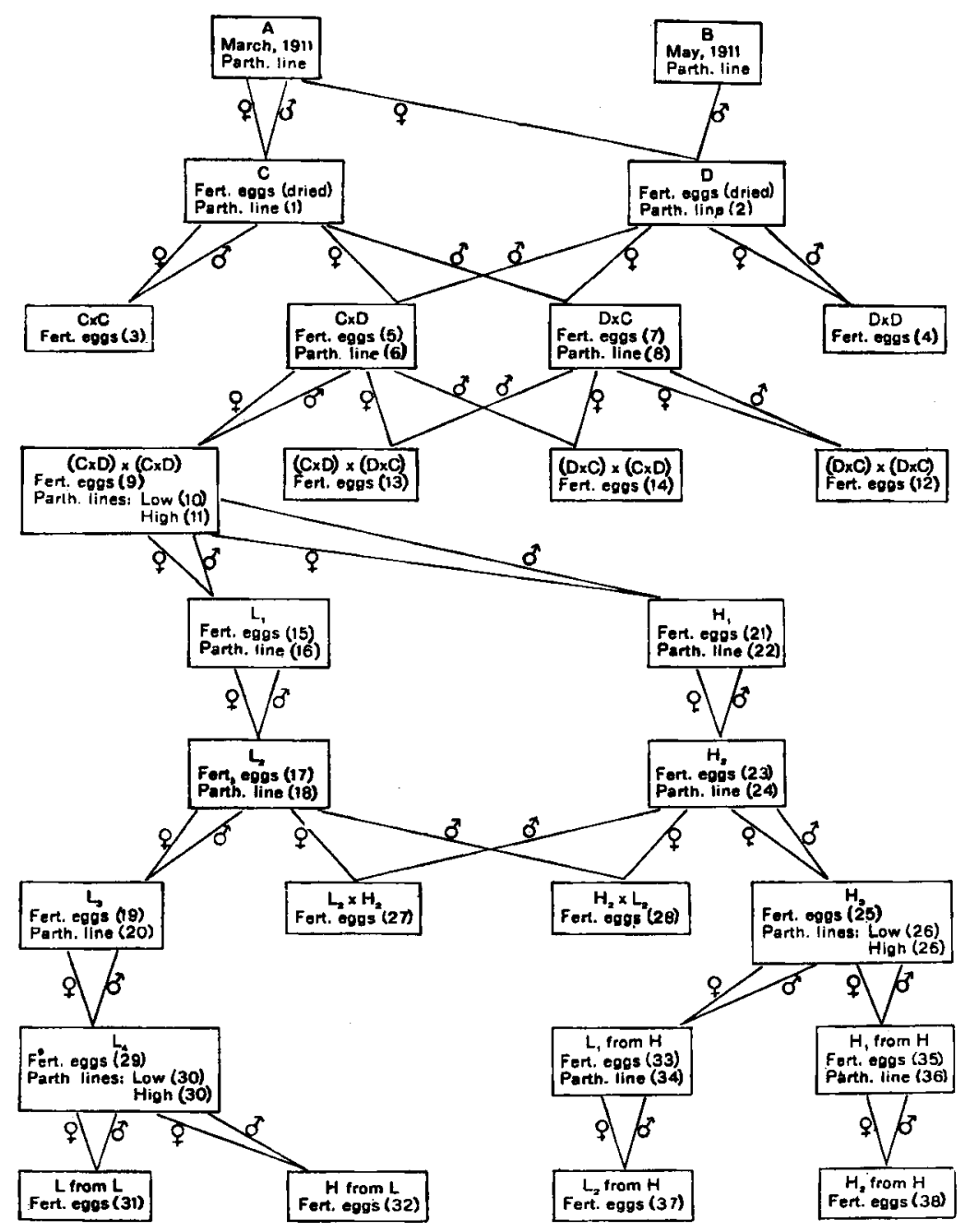

Fig. 1 Diagram showing the relation of the experiments to each other. The parthenogenetic line in each rectangle was derived from one of the fertilized eggs in the same rectangle. Letters at the top of the rectangles refer to experiments; numbers in parentheses refer to tables. 
TABLE 1

Showing details of the parthenogenetic line $C$ in figure 1. Male-producers are designated $\sigma^{7} \%$, female-producers $\%$ \%

\begin{tabular}{|c|c|c|c|c|c|c|c|}
\hline $\begin{array}{l}\text { NUMBER OF } \\
\text { GENERATION }\end{array}$ & $\begin{array}{c}\text { DATE OF } \\
\text { FIRS2 } \\
\text { YOUNG }\end{array}$ & $\underset{\substack{\text { NUMBER } \\
\sigma^{7}}}{\text { or }}$ & $\mid \begin{array}{c}\text { NUMBER OF } \\
9 \%\end{array}$ & $\begin{array}{l}\text { NUMBER OF } \\
\text { GENERATION }\end{array}$ & $\begin{array}{c}\text { DATE OF } \\
\text { FIRST } \\
\text { YOUNG }\end{array}$ & $\begin{array}{c}\text { NUMBER or } \\
0^{7} \&\end{array}$ & NOMBER Or \\
\hline 1 & Oct. 12 & 35 & 16 & 5 & Oet. 20 & 1 & 11 \\
\hline 2 & 14 & 23 & 25 & & 21 & 30 & 22 \\
\hline 3 & 17 & 0 & 21 & 6 & 22 & 43 & 8 \\
\hline 4 & 18 & 33 & 16 & 7 & 27 & 0 & 16 \\
\hline & & & & 8 & 29 & 23 & 14 \\
\hline \multicolumn{6}{|l|}{ Total. } & 188 & 149 \\
\hline
\end{tabular}

Percentage of $\sigma^{7} q \ldots \ldots \ldots \ldots \ldots \ldots \ldots \ldots \ldots \ldots$ 55.7

when water was put on them. On September 9 one female hatched, from which was bred the parthenogenetic line designated $C$ in figure 1 . The details of this line are given in table 1 .

$D$. Females of line $A$ were mated with males of line $B$ on June 24 and 25, 1911, and laid on the average 10.9 eggs apiece. These eggs were dried and remained in this condition until August 30 , when they were again covered with water. One female hatched on September 2 and gave rise to line $D$ of figure 1, the details of which are shown in table 2.

\section{Viability in crosses and in inbreeding}

$C \times C$. Females of line $C$ were mated with males of the same line October 22 to 26, 1911. From the 50 matings thus made, 805 fertilized eggs, or 16.1 per female, were obtained. These eggs were kept under observation until December 20 to determine what proportion of them would hatch. Table 3 gives the details of the hatching. It appears that $368 \mathrm{eggs}$, or 45.7 per cent of the whole lot, were viable. It is also worthy of note that the number hatching daily gradually increased up to the fifth or sixth day, and thereafter, with certain fluctuations, decreased. Furthermore, practically the whole lot of viable eggs hatched within a period of twelve or thirteen days, though the eggs were kept much longer. The brief period in which the hatching occurred is in such contrast with the case next to be described that $I$ have sought some method of measuring it. As 
TABLE 2

Showing details of parthenogenetic line $D$ in figure 1

\begin{tabular}{|c|c|c|c|c|c|c|c|}
\hline $\begin{array}{l}\text { NUMBER OF } \\
\text { GENERATION }\end{array}$ & $\begin{array}{c}\text { DATE oY } \\
\text { FIRST } \\
\text { YOUNG } \\
\end{array}$ & $\begin{array}{c}\text { NUMBER } \\
\sigma^{2}+9\end{array}$ & OF NUMBER OF & $\begin{array}{c}\text { NUMBER OF } \\
\text { GENERATION }\end{array}$ & $\begin{array}{c}\text { DATE OF } \\
\text { PIRST } \\
\text { YOUNG } \\
\end{array}$ & $\begin{array}{c}\text { NUMBER OF } \\
\text { O" }^{*} ?\end{array}$ & $\begin{array}{c}\text { NUMBER OF } \\
\text { O } 9\end{array}$ \\
\hline 1 & Sep. 3 & 0 & 5 & 18 & Oet. 1 & 6 & 45 \\
\hline 2 & 5 & 0 & 22 & 19 & 3 & 30 & 19 \\
\hline 3 & 7 & 0 & 23 & 20 & 5 & 8 & 41 \\
\hline 4 & 9 & 0 & 46 & 21 & 7 & 10 & 39 \\
\hline 5 & 10 & 0 & 26 & 22 & 9 & 22 & 22 \\
\hline 6 & 12 & 0 & 46 & 23 & 11 & 0 & 50 \\
\hline 7 & 14 & 4 & 19 & 24 & 13 & 32 & 16 \\
\hline 8 & 16 & 6 & 23 & 25 & 15 & 20 & 18 \\
\hline 9 & 17 & 0 & 26 & 26 & 17 & 23 & 22 \\
\hline 10 & 19 & $\mathbf{0}$ & 28 & 27 & 19 & 6 & 36 \\
\hline 11 & 20 & 7 & 45 & 28 & 21 & 18 & 27 \\
\hline 12 & 22 & 11 & 44 & 29 & 23 & 5 & 44 \\
\hline 13 & 23 & 7 & 44 & 30 & 25 & 1 & 41 \\
\hline 14 & 25 & 3 & 44 & 31 & 28 & 16 & 28 \\
\hline 15 & 26 & 9 & 40 & 32 & 30 & 3 & 40 \\
\hline 16 & 28 & 2 & 48 & 33 & Nov. 2 & 19 & 21 \\
\hline 17 & 29 & 14 & 30 & & & & \\
\hline \multicolumn{6}{|l|}{ Total. } & . 282 & 1068 \\
\hline \multicolumn{6}{|c|}{ 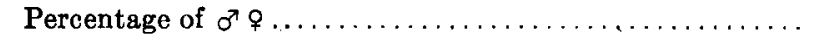 } & \multicolumn{2}{|c|}{20.8} \\
\hline
\end{tabular}

TABLE 3

Showing number of eggs that hatched, out of 805 in lot $C \times C$, figure 1

\begin{tabular}{|c|c|c|c|c|c|}
\hline DATE & $\begin{array}{l}\text { NUMBER } \\
\text { HATCHED }\end{array}$ & DATE & $\begin{array}{r}\text { NUMBER } \\
\text { HATCHED }\end{array}$ & DATE & $\begin{array}{l}\text { NUMBER } \\
\text { HATCHED }\end{array}$ \\
\hline Nov. 1 & 7 & Nov. 7 & 28 & Nov. 13 & 2 \\
\hline 2 & 19 & 8 & 28 & 14-15 & 0 \\
\hline 3 & 14 & 9 & 65 & 16 & 1 \\
\hline 4 & 33 & 10 & 15 & 17-Dec. 3 & 0 \\
\hline 5 & 83 & 11 & 8 & 4 & 1 \\
\hline 6 & 63 & 12 & 1 & $5-20$ & 0 \\
\hline \multicolumn{5}{|c|}{ 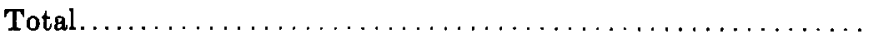 } & 368 \\
\hline
\end{tabular}

Percentage of viable eggs. .

.45 .7

Standard deviation: $\sigma_{\mathrm{H}}=2.83 \quad \sigma_{\mathrm{L}}=1.74$ 
the curve of hatching is similar to a probability curve, the variability of the hatching time may be measured by the standard deviation. This is obtained by the formula $\sigma=\sqrt{\frac{\Sigma p a^{2}}{n}}$, in which $p$ is the number hatching each day, $a$ the deviation from the mean duration of the egg stage, and $n$ the total number hatching. The standard deviation in this case, as shown at the bottom of table 3 , is 2.83 (days). A comparatively low standard deviation indicates that the hatching occurred within a brief period. A certain correction may be necessary, but this will be mentioned later.

$D \times D$. Females of line $D$ were mated with males of the same line October 22 to 31,1911 . From 32 matings thus made, 543 eggs, or 16.9 per female, were secured. These eggs were kept under observation until December 20, during which time 29, or 5.3 per cent hatched. There was great variability in the hatching time of these 29 eggs, that is, the hatching was spread nearly evenly over four weeks, with scattering ones later, as shown in table 4, instead of over two weeks as in $C \times C$. This is shown by the high standard deviation, $\sigma=10.78$.

TABLE 4

Showing number of eggs that hatched, out of 543 in lot $D \times D$, figure 1

\begin{tabular}{|c|c|c|c|c|c|}
\hline DATE & $\begin{array}{l}\text { NUMBFR } \\
\text { EATCHED }\end{array}$ & DATE & $\begin{array}{l}\text { NOMBER } \\
\text { HATCHED }\end{array}$ & DATE & $\begin{array}{l}\text { NOMBER } \\
\text { HATCHED }\end{array}$ \\
\hline Nov. 4 & 1 & Nov. 16 & 1 & Dec. 1 & 2 \\
\hline 5 & 1 & $17-18$ & 0 & 2 & 0 \\
\hline $6-8$ & 0 & 19 & 1 & 3 & 1 \\
\hline 9 & 1 & 20 & 3 & 4 & 1 \\
\hline 10 & 2 & 21 & 0 & $5-8$ & 0 \\
\hline 11 & 0 & 22 & 2 & 9 & 1 \\
\hline 12 & 1 & 23 & 1 & 10 & 0 \\
\hline 13 & 3 & $24-25$ & $\mathbf{0}$ & 11 & 1 \\
\hline 14 & 1 & 26 & 1 & $12-17$ & 0 \\
\hline 15 & 3 & $27-30$ & 0 & 18 & 1 \\
\hline & & & & $19-20$ & 0 \\
\hline \multicolumn{5}{|l|}{ Total. } & 29 \\
\hline
\end{tabular}

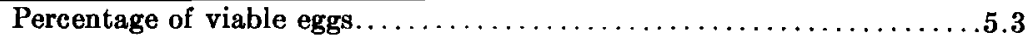

Standard deviation: $\sigma_{\mathrm{H}}=10.78 \quad \sigma_{\mathrm{L}}=3.64$ 
These inbred eggs are so different from those of $C \times C$, both in their percentage of viability and in the variability of the duration of the egg stage, that reciprocal crosses between the lines producing them $(C$ and $D)$ are of considerable interest. These crosses are next described.

$C \times D$. Females of line $C$ were mated with males of line $D$ October 14 to 16 and 20 to 21, 1911. From 55 such matings were obtained 827 eggs. These were observed daily until December 4 , at which time 426 , or 51.5 per cent had hatched. More than half the eggs were observed eight days longer, but none of them hatched, so the 426 recorded up to December 4 are probably about the total. Table 5 gives the details of the hatching. The eggs were obtained in two distinct lots, separated by an interval of several days, and these lots were observed separately. In the table, they are combined, and instead of the actual date the day of hatching, counting from the day the first egg was laid, is given in the table. From this table it appears that the variability of the duration of the egg stage is larger than in $C \times C$, but much smaller than in $D \times D(\sigma=3.44$.).

A parthenogenetic line, started from a female selected at random from the third day's hatch is recorded in table 6 . The proportion of male-producers in this line was 44.6 per cent.

TABLE 5

Showing number of eggs that hatched, out of 827 in lot $C \times D$, figure 1

\begin{tabular}{|c|c|c|c|c|c|}
\hline $\begin{array}{c}\text { DAY OF } \\
\text { HATCHING }\end{array}$ & $\begin{array}{l}\text { NUMBER } \\
\text { HATCHED }\end{array}$ & $\begin{array}{c}\text { DAY OF } \\
\text { HATCHING }\end{array}$ & $\begin{array}{c}\text { NUMER } \\
\text { HATCHED }\end{array}$ & $\begin{array}{c}\text { DAY OF } \\
\text { HATCHING }\end{array}$ & $\begin{array}{r}\text { NUMBER } \\
\text { HATCHED }\end{array}$ \\
\hline 7 & 8 & 14 & 31 & 24 & 2 \\
\hline 8 & 34 & 15 & 16 & $25-31$ & 0 \\
\hline 9 & 47 & 16 & 8 & 32 & 1 \\
\hline 10 & 120 & 17 & 5 & $33-45$ & 0 \\
\hline 11 & 66 & 18 & 12 & 46 & 1 \\
\hline 12 & 35 & 19 & 5 & $47-49$ & 0 \\
\hline 13 & 35 & $20-23$ & 0 & & \\
\hline \multicolumn{5}{|c|}{ 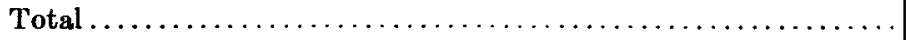 } & 426 \\
\hline \multicolumn{5}{|c|}{ 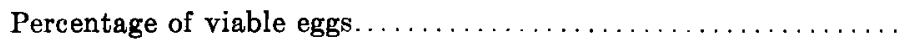 } & 51.5 \\
\hline \multicolumn{6}{|c|}{ Standard deviation: $\sigma_{\mathrm{H}}=3.44$} \\
\hline
\end{tabular}


$D \times C$. Females of line $D$ were mated with males of line $C$ October 16 to 21,1911 . From 47 such matings were obtained 660 eggs which were kept under observation until December 8, at which time 214 eggs, or 32.4 per cent, had hatched. Half the eggs were kept until December 20, and two more were hatched; but these two are not included in table 7 as they would not greatly

TABLE 6

Showing details of parthenogenetic line $C \times D$, figure 1

\begin{tabular}{|c|c|c|c|c|c|c|c|}
\hline $\begin{array}{l}\text { NUMBER OF } \\
\text { GENERATION }\end{array}$ & $\begin{array}{l}\text { DATE OF } \\
\text { FIRST } \\
\text { YOUNG }\end{array}$ & $\begin{array}{c}\text { NUMBER } \\
\text { OF } \\
O^{\prime} \&\end{array}$ & $\begin{array}{c}\text { NUMHER } \\
\text { OF } \\
\wp \%\end{array}$ & $\begin{array}{l}\text { NUMBER OF } \\
\text { GENERATION }\end{array}$ & $\begin{array}{l}\text { DATE OF } \\
\text { FIRST } \\
\text { YOUNG }\end{array}$ & $\begin{array}{c}\text { NUMBER } \\
\text { OF } \\
O^{\prime \prime} P\end{array}$ & $\begin{array}{c}\text { NUMBER } \\
\text { OF } \\
\wp \&\end{array}$ \\
\hline 1 & Nov. 3 & 23 & 32 & 5 & Nov. 22 & 18 & 29 \\
\hline 2 & 5 & 16 & 24 & 6 & 24 & 26 & 25 \\
\hline 3 & 7 & $21^{1}$ & $24^{1}$ & 7 & 26 & 32 & 17 \\
\hline 4 & 10 & $0^{1}$ & $15^{1}$ & 8 & 28 & $9^{1}$ & $14^{1}$ \\
\hline \multicolumn{6}{|l|}{ Total } & 145 & 180 \\
\hline \multicolumn{8}{|c|}{ 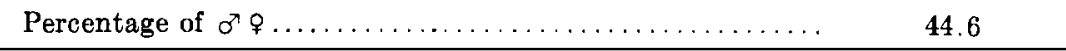 } \\
\hline
\end{tabular}

1 Remainder of family not recorded.

TABLE 7

Showing number of eggs that hatched, out of 660 in lot $D \times C$, figure 1

\begin{tabular}{|c|c|c|c|c|c|c|}
\hline \multicolumn{2}{|l|}{ DATE } & $\begin{array}{l}\text { NUMBER } \\
\text { HATCHED }\end{array}$ & DATE & $\begin{array}{l}\text { NUMBER } \\
\text { HATCEED }\end{array}$ & DATE & $\begin{array}{l}\text { NUMBER } \\
\text { HATCHED }\end{array}$ \\
\hline Oct. & 26 & 7 & Nov. 7 & 0 & Nov. & 1 \\
\hline & 27 & 31 & 8 & 2 & 20 & 4 \\
\hline & 28 & 21 & 9 & $20^{\circ}$ & 21 & 0 \\
\hline & 29 & 9 & 10 & 19 & 22 & 1 \\
\hline & 30 & 9 & 11 & 13 & 23 & 3 \\
\hline & 31 & 1 & 12 & 2 & 24 & 1 \\
\hline Nov. & 1 & 3 & 13 & 9 & $25-26$ & 0 \\
\hline & 2 & 11 & 14 & 1 & 27 & 1 \\
\hline & 3 & 8 & 15 & 1 & 28-Dec. 5 & 0 \\
\hline & 4 & 6 & 16 & 3 & 6 & 1 \\
\hline & 5 & 4 & 17 & 0 & 7 & 1 \\
\hline & 6 & 20 & 18 & 1 & 8 & 0 \\
\hline \multicolumn{6}{|c|}{ 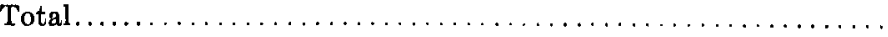 } & 214 \\
\hline
\end{tabular}

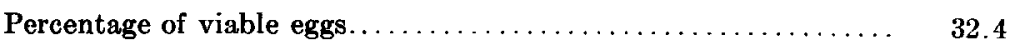

Standard deviation: $\sigma_{H}=7.79 \quad \sigma_{L}=2.15$ 
affect the result. The standard deviation of the duration of the egg stage is 7.79 , less than in $D \times D$, but considerably greater than in $C \times C$ or $C \times D$. The hatching has been spread over a considerable time, but not so great a time, relative to the number hatching, as in $D \times D$.

Some correction in the standard deviation of the duration of the egg stage seems necessary. If the eggs be collected over a long period, and all be put into one lot for records of hatching, it is obvious that the hatching will be spread over a correspondingly longer period, and the standard deviation thereby increased. Since the four lots of eggs to be compared $(C \times C$, $C \times D, D \times C$ and $D \times D)$ were not obtained in the same length of time, the apparent variability of the duration of the egg stage is not the true variability. To correct this error in some measure, I have computed the standard deviation of the laying of the eggs, and deducted it from the standard deviation of the hatching. Some computation was necessary to determine when the eggs were laid; but as the number of females mated in one day, and the number of eggs laid by each, is known, and as the fertilized eggs of one female are laid over a period of about five days, a fair approximation of the time of laying may be had. After this adjustment, the standard deviation was computed, and is given at the bottom of each of the four tables of hatching (indicated by $\sigma_{\mathrm{L}} ; \sigma_{\mathrm{H}}$ indicates the standard deviation of hatching). It is believed that deducting $\sigma_{\mathrm{L}}$ from $\sigma_{\mathrm{I}}$ is a sufficiently accurate correction within the limits in which it is used.

If, now, the four lots to be compared are arranged in a series, as in figure 1, with the inbred eggs $(C \times C$ and $D \times D)$ at the ends, and the reciprocal crosses between them, each one nearest the line that furnished the female parent, some interesting facts appear. The standard deviations of hatching of the four lots are 2.83, 3.44, 7.79 and 10.78, respectively; or, if we deduct from each the standard deviation of laying, they are 1.09, 1.87, 5.64 and 7.14. From left to right, these four lots of eggs form a series of increasing variability of the duration of the egg stage. The most important feature is that the reciprocal crosses are 
apparently unequal. While both lie between the extremes of their parents, each is more like the line that furnished its female parent.

This inequality of the reciprocal crosses also appears in the percentage of viable eggs. If the series be again arranged in the same order as in figure 1, these percentages are 45.7, 51.5, 32.4 and 5.3, respectively. Of the two reciprocal crosses, the one whose mother came from the high viability line had the more viable eggs, and conversely. The apparent inequality of the reciprocals is further tested in the experiments next to be described.

It should be mentioned here in passing that from one of the eggs of lot $D \times C$, that hatched on the third day of hatching, a parthenogenetic line was reared as in table 8 . The percentage of male-producers was 31.2 .

$(C \times D) \times(C \times D)$. Females of the parthenogenetic line $C \times D$ were paired with males of the same line November 24 to 30,1911 . From 54 matings thus made, 904 eggs were secured. These eggs were observed daily until December 20, by which time 425 , or 47.0 per cent, had hatched. Table 9 records the complete data. The standard deviation of the duration of the egg stage is found to be 2.30 . It does not seem necessary to

TABLE 8

Showing details of parthenogenetic line $D \times C$, figure 1

\begin{tabular}{|c|c|c|c|c|c|c|c|}
\hline $\begin{array}{c}\text { NOMBER } \\
\text { OF } \\
\text { GENERATION }\end{array}$ & $\begin{array}{l}\text { DATE OF } \\
\text { FTRST } \\
\text { YOUNG }\end{array}$ & $\underset{\substack{\text { NOMBER } \\
\sigma^{3}+}}{\text { Of }}$ & 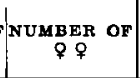 & $\begin{array}{c}\text { NUMBER } \\
\text { OF } \\
\text { GENERATION }\end{array}$ & $\begin{array}{c}\text { DATE OF } \\
\text { FIRST } \\
\text { YOUNG }\end{array}$ & $\begin{array}{c}\text { MUMBER OF } \\
0^{7} ?\end{array}$ & $\begin{array}{c}\text { NUMBer or } \\
\& \%\end{array}$ \\
\hline 1 & Nov. 4 & 2 & 23 & 5 & Nov. 21 & $1^{1}$ & $21^{1}$ \\
\hline 2 & 5 & 12 & 38 & 6 & 23 & 9 & 22 \\
\hline \multirow[t]{2}{*}{3} & 8 & $12^{1}$ & $18^{1}$ & 7 & 25 & 35 & 13 \\
\hline & 9 & $1^{1}$ & $21^{1}$ & 8 & 28 & 12 & 22 \\
\hline 4 & 10 & $1^{1}$ & $9^{1}$ & & & & \\
\hline \multicolumn{6}{|l|}{ Total. } & 85 & 187 \\
\hline
\end{tabular}

Percentage of $\sigma^{7} \%$

31.2

\footnotetext{
1 Remainder of family not recorded.
} 
compute the standard deviation of laying, since in the four experiments to be compared the number of days on which the eggs were obtained does not vary so greatly.

To test whether the viability of the eggs could be altered by selection, two parthenogenetic lines were started from fertilized eggs of the lot $(C \times D) \times(C \times D)$. Of the 54 females laying these eggs, twelve were kept isolated and the hatching of their eggs abserved separately. There was considerable variation in the proportion of the various families that hatched. The least viable family hatched 4 out of 18 eggs, or 22.2 per cent of the family. From the first of the 4 that hatched a parthenogenetic line was reared, as in table 10 . The most viable family hatched 11 out of 15 , or 73.3 per cent. From the first of the 11 that hatched a parthenogenetic line was reared, as in table 11. The

TABLE 9

Showing number of eggs that hatched, out of 904 in lot $(C \times D) \times(C \times D)$, figure 1

\begin{tabular}{|c|c|c|c|c|c|}
\hline DATE & $\begin{array}{l}\text { NCMBER } \\
\text { HATCBED }\end{array}$ & DATE & $\begin{array}{r}\text { NUMBER } \\
\text { HATCHED }\end{array}$ & DATE & $\begin{array}{l}\text { NUMBER } \\
\text { HATCHED }\end{array}$ \\
\hline Dec. & 4 & Dec. 12 & 107 & Dec. 17 & 0 \\
\hline & 8 & 13 & 87 & 18 & 12 \\
\hline & 13 & 14 & 10 & 19 & $\mathbf{0}$ \\
\hline & 58 & 15 & 6 & 20 & 4 \\
\hline & 114 & 16 & 2 & & \\
\hline \multicolumn{5}{|c|}{ Total } & 425 \\
\hline
\end{tabular}

Percentage of viable eggs.......................... 47.0

Standard deviation: $\sigma_{\mathrm{H}}=2.30$

TABLE 10

Showing details of parthenogenetic line derived from low viability family in $(C \times D) \times(C \times D)$, figure 1

\begin{tabular}{|c|c|c|c|c|c|c|c|}
\hline $\begin{array}{l}\text { NUMBER OF } \\
\text { GENERATION }\end{array}$ & $\begin{array}{c}\text { DATE OF } \\
\text { FIRST } \\
\text { YOUNG }\end{array}$ & $\begin{array}{c}\text { NUMBER } \\
\text { OF } \\
\sigma^{2} \%\end{array}$ & $\begin{array}{c}\text { NUMBER } \\
\text { OF } \\
\$ \%\end{array}$ & $\begin{array}{l}\text { NUMBER OF } \\
\text { GENERATION }\end{array}$ & $\begin{array}{c}\text { DATE OF } \\
\text { FIRST } \\
\text { YOUNG }\end{array}$ & $\begin{array}{c}\text { NUMBER } \\
\text { OF } \\
\sigma^{\top} q\end{array}$ & $\begin{array}{c}\text { NUMBER } \\
\text { OF } \\
9 \%\end{array}$ \\
\hline 1 & Jan. 11 & 6 & 35 & 3 & Jan. 15 & 17 & 30 \\
\hline 2 & 13 & 9 & 29 & 4 & 16 & 31 & 14 \\
\hline \multicolumn{6}{|l|}{ Total. } & 63 & 107 \\
\hline \multicolumn{8}{|c|}{ 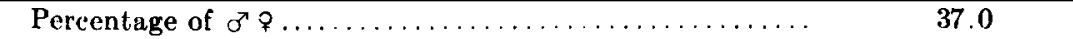 } \\
\hline
\end{tabular}


effect of this selection on viability is described later under the headings $L_{1}$ and $\boldsymbol{H}_{1}$. I merely call attention here to the difference in the proportion of male-producers, 37.0 per cent in one line, 20.5 per cent in the other.

$(D \times C) \times(D \times C)$. Females of the parthenogenetic line $D \times C$ were mated with males of the same line November 26 to 30,1911 . From 38 such matings were secured 576 eggs. By December 20, when the hatching must have been nearly complete, 319 of these eggs, or 55.3 per cent had hatched (table 12). The greater number of these eggs were hatched on a few successive days, hence the standard deviation is low $(\sigma=1.65)$.

TABLE 11

Showing details of parthenogenetic line derived from high viability family in $(C \times D) \times(C \times D)$, figure 1

\begin{tabular}{|c|c|c|c|c|c|c|c|}
\hline $\begin{array}{c}\text { NUMBER } \\
\text { OF } \\
\text { GENERATION }\end{array}$ & $\begin{array}{l}\text { DATE OF } \\
\text { FIRST } \\
\text { YOUNA }\end{array}$ & $\begin{array}{c}\text { NUMBER } \\
O^{\prime} \&\end{array}$ & 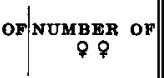 & $\begin{array}{c}\text { NUMBER } \\
\text { OF } \\
\text { GENERATION }\end{array}$ & $\begin{array}{c}\text { DATE OF } \\
\text { FIRET } \\
\text { YOUNG }\end{array}$ & $\begin{array}{c}\text { NUMBER OF } \\
\sigma^{7} \%\end{array}$ & FUMBER OF \\
\hline 1 & Jan. 11 & 0 & 14 & 6 & Jan. 21 & 8 & 30 \\
\hline 2 & 13 & 0 & 17 & & 21 & 6 & 23 \\
\hline 3 & 15 & 0 & 9 & 7 & 21 & 8 & 11 \\
\hline 4 & 17 & 6 & 42 & 8 & 23 & 10 & 34 \\
\hline 5 & 18 & 21 & 29 & 9 & 25 & 8 & 28 \\
\hline 6 & 20 & 4 & 29 & & 25 & 5 & 28 \\
\hline \multicolumn{6}{|l|}{ Total. } & 76 & 294 \\
\hline
\end{tabular}

TABLE 12

Showing number of eggs that hatched, out of 576 in $(D \times C) \times(D \times C)$, figure 1

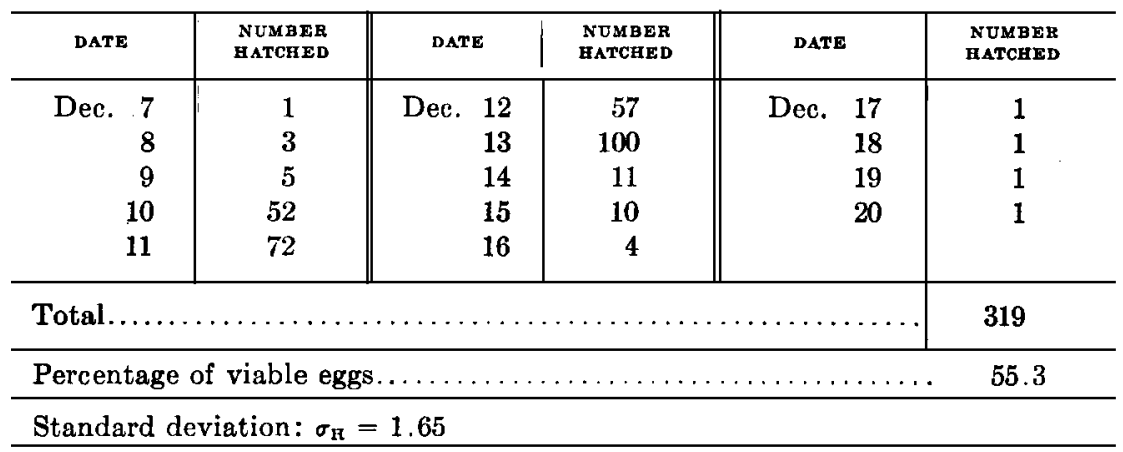


Attention may now be called to the fact that although the eggs of $D \times C$ showed lower viability and greater variability in the duration of the egg stage than did those of $C \times D$, yet when the parthenogenetic lines from each were inbred, the eggs in lot $(D \times C) \times(D \times C)$ were a little more viable and a little less variable in their hatching time than were those of $(C \times D)$ $\times(C \times D)$. The differences are small, however, as compared with the differences between $D \times C$ and $C \times D$, and are probably insignificant. The inequality of the reciprocal crosses disappears when the parthenogenetic lines derived from them are compared. Further evidence that the reciprocal crosses $C \times D$ and $D \times C$ are not after all unequal is found in the reciprocal crosses between the reciprocal crosses, now to be described.

$(C \times D) \times(D \times C)$. Females from the parthenogenetic line $C^{\prime} \times D$ were paired with males from line $D \times C$ November 9 and 10, 1911. From 20 matings thus produced, 278 eggs were obtained. Up to December 20, 174 of these eggs, or 62.5 per cent, had hatched (table 13). The duration of the egg stage is not greatly variable, hence the standard deviation is low $(\sigma=2.42)$.

$(D \times C) \times(C \times D)$. Females of the line $D \times C$ were mated with males of the line $C \times D$ November 7 to 10,1911 . From 23 such matings were secured 357 eggs. Up to December 20,

TABLE 13

Showing number of eggs that hatched, out of 278 in $(C \times D) \times(D \times C)$, figure 1

\begin{tabular}{|c|c|c|c|c|c|}
\hline DATE & $\begin{array}{c}\text { NUMBER } \\
\text { HATCHED }\end{array}$ & DATE & $\begin{array}{c}\text { NUMBER } \\
\text { HATCHED }\end{array}$ & DATE & $\begin{array}{c}\text { NUMBER } \\
\text { HATCEED }\end{array}$ \\
\hline Nov. 19 & 5 & Nov. 25 & 10 & Dec. 1-5 & 0 \\
\hline 20 & 9 & 26 & 2 & 6 & 1 \\
\hline 21 & 20 & 27 & 1 & $7-14$ & 0 \\
\hline 22 & 59 & 28 & 0 & 15 & 1 \\
\hline 23 & 44 & 29 & 1 & $16-20$ & 0 \\
\hline 24 & 19 & 20 & 2 & & \\
\hline \multicolumn{5}{|c|}{ 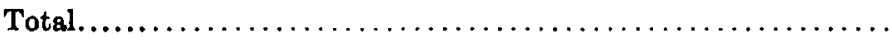 } & 174 \\
\hline \multicolumn{5}{|c|}{ Percentage of viable eggs $\ldots \ldots \ldots \ldots \ldots \ldots \ldots \ldots \ldots \ldots \ldots$} & 62.5 \\
\hline \multicolumn{6}{|c|}{ Standard deviation: $\sigma_{\mathrm{H}}=2.42$} \\
\hline
\end{tabular}


244 of these eggs, or 68.3 per cent, had hatched (table 14). The variability in hatching time is not great, hence the standard deviation is low $(\sigma=2.19)$.

The reciprocal crosses described in the last two paragraphs are approximately equal both in percentage of viability, and in variability of hatching time, though their parents $C \times D$ and $D \times C$, were widely different in both characters. This supports similar evidence from the inbreeding of $C \times D$ and the inbreeding of $D \times C$. The reciprocal crosses $C \times D$ and $D \times C$ were,

TABLE 14

Showing number of eggs that hatched, out of 957 in $(D \times C) \times(C \times D)$, figure 1

\begin{tabular}{r|r|r|r|r|r}
\hline \multicolumn{1}{c|}{ DATE } & $\begin{array}{c}\text { NUMBER } \\
\text { HATCHED }\end{array}$ & \multicolumn{1}{|c|}{ DATE } & $\begin{array}{c}\text { NOMBER } \\
\text { HATCHED }\end{array}$ & DATE & $\begin{array}{c}\text { NUMBER } \\
\text { HATCHED }\end{array}$ \\
\hline Nov. 18 & 3 & Nov. 23 & 53 & Nov. 28 & 2 \\
19 & 14 & 24 & 30 & 29 & 0 \\
20 & 16 & 25 & 26 & 30 & 1 \\
21 & 19 & 26 & 17 & Dec. $1-6$ & 0 \\
22 & 59 & 27 & 3 & $8-20$ & 0 \\
& & & & & \\
\hline
\end{tabular}

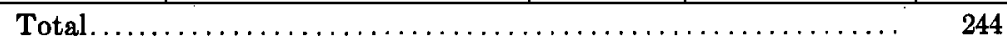

Percentage of viable eggs.......................... 68.3

Standard deviation: $\sigma_{\mathrm{H}}=2.19$

after all, nearly equal. The inequality existed only in the egg stage. When these eggs grew up, so to speak, to produce parthenogenetic lines, these lines were essentially equal in the viability and variability of the fertilized eggs which they produced.

Effect of selection for low viability in a hybrid line

$L_{1}$. Females of the parthenogenetic line derived from a low viability parent in $(C \times D) \times(C \times D)$ were paired with males of the same line January 16 to 18,1912 . From 40 such matings, 515 eggs were obtained. These were kept under observation until February 22, at which time 149 eggs, or 28.9 per cent, had hatched (table 15). Standard deviation of hatching time has not been computed for any of the selection experiments, as it was obvious that no marked difference would be found. 
Of the 40 females laying these eggs, 12 were kept isolated and the hatching of their eggs recorded separately. The least viable of these twelve families of eggs was one that hatched only 1 out of 21 (viability 4.7 per cent). From the one that hatched, a parthenogenetic line was reared (table 16) to produce a further generation of eggs. This line included 39.3 per cent of maleproducers.

$L_{2}$. Females of the parthenogenetic line $L_{1}$ were paired with males of the same line February 14 to 24, 1912. From 60 matings thus made were obtained 770 eggs. By March 17, when observations ceased, 272 eggs, or 35.3 per cent, had hatched (table 17).

From the 60 females that laid these eggs, one was selected that laid 18 eggs, of which but one hatched (viability 5.5 per cent). From this one was bred a parthenogenetic line (table

TABLE 15

Showing number of eggs that hatched, out of 515 in lot $L_{1}$, figure 1

\begin{tabular}{|c|c|c|c|c|c|}
\hline DATE & $\begin{array}{l}\text { NUMBER } \\
\text { HATCHED }\end{array}$ & DATE & $\begin{array}{l}\text { NUMBER } \\
\text { HATCHED }\end{array}$ & DATE & $\begin{array}{l}\text { NUMBER } \\
\text { HATCHED }\end{array}$ \\
\hline $\begin{array}{r}\text { Jan. } 26 \\
27 \\
28 \\
29 \\
30\end{array}$ & $\begin{array}{r}5 \\
14 \\
2 \\
10 \\
64\end{array}$ & $\begin{array}{rr}\text { Jan. } & 31 \\
\text { Feb. } & 1 \\
2 \\
3 \\
4-7\end{array}$ & $\begin{array}{r}23 \\
6 \\
0 \\
1 \\
0\end{array}$ & $\begin{array}{rr}\text { Feb. } & 8 \\
& 9 \\
10 \\
11-22\end{array}$ & $\begin{array}{r}11 \\
12 \\
1 \\
0\end{array}$ \\
\hline \multicolumn{5}{|c|}{ 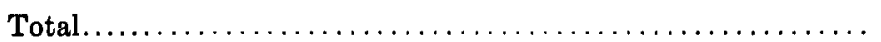 } & 149 \\
\hline Percentag & iable e & & & & .28 \\
\hline
\end{tabular}

TABLE 16

Showing details of parthenogenetic line $L_{1}$, figure 1

\begin{tabular}{|c|c|c|c|c|c|c|c|}
\hline $\begin{array}{c}\text { NOMBER } \\
\text { OF } \\
\text { GENERATION }\end{array}$ & $\begin{array}{l}\text { DATE OF } \\
\text { FIRST } \\
\text { YOUNG }\end{array}$ & 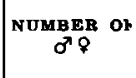 & $\mid \begin{array}{c}\text { NOMBER OF } \\
\stackrel{q}{q}\end{array}$ & $\begin{array}{c}\text { NUMBER } \\
\text { OF } \\
\text { GENERATION }\end{array}$ & $\begin{array}{l}\text { DATR OF } \\
\text { FIRBT } \\
\text { YOUNG }\end{array}$ & $\begin{array}{c}\text { XUMBER OF } \\
\sigma^{n}+9\end{array}$ & $\mid \begin{array}{c}\text { NUMBER OP } \\
9 \%\end{array}$ \\
\hline 1 & Feb. 8 & 10 & 31 & 4 & Feb. 15 & 24 & 19 \\
\hline 2 & 10 & 24 & 22 & 5 & 17 & 10 & 39 \\
\hline 3 & 12 & 24 & 19 & & & & \\
\hline \multicolumn{6}{|l|}{ Total. } & 92 & 142 \\
\hline
\end{tabular}

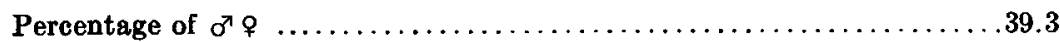


18) to be used for further selection for least viable eggs. This line included 40.7 per cent of male-producers.

$L_{3}$. Females of the parthenogenetic line $L_{2}$ were paired with males of the same line April 3 to 8, 1912. From 42 such matings, 487 eggs were obtained. To and including April 30, there had hatched 191 eggs, or 39.2 per cent (table 19).

From the 191 eggs that hatched, one was selected at random, without reference to the viability of the family to which it belonged. From this egg a parthenogenetic line was reared (table 20) which included 36.1 per cent of male-producers.

TABLE 17

Showing number of eggs that hatched, out of 770 in lot $L_{2}$. fioure 1

\begin{tabular}{|c|c|c|c|c|c|}
\hline DATE & $\begin{array}{l}\text { NUMBER } \\
\text { HATCHED } \\
\end{array}$ & DASE & $\begin{array}{l}\text { NUMBER } \\
\text { HATCHED } \\
\end{array}$ & DATE & $\begin{array}{r}\text { NUMBER } \\
\text { HATCHED }\end{array}$ \\
\hline Feb. 24 & 20 & Mar. 1 & 26 & Mar. 7 & 2 \\
\hline 25 & 30 & 2 & 31 & $8-10$ & 0 \\
\hline 26 & 16 & 3 & 9 & 11 & 2 \\
\hline 27 & 29 & 4 & 8 & 12 & 0 \\
\hline 28 & 52 & 5 & 12 & 13 & 5 \\
\hline \multirow[t]{2}{*}{29} & 29 & 6 & $\mathbf{0}$ & 14 & 1 \\
\hline & & & & $15-17$ & 0 \\
\hline tal. & & & & & 272 \\
\hline
\end{tabular}

Percentage of viable eggs. $\ldots \ldots \ldots \ldots \ldots \ldots \ldots \ldots \ldots \ldots \ldots \ldots, \quad 35.3$

TุABLE 18

Showing details of parthenogenetic line in $L_{2}$, figure 1

\begin{tabular}{|c|c|c|c|c|c|c|c|}
\hline $\begin{array}{c}\text { NUMBER } \\
\text { OF } \\
\text { GENERATION }\end{array}$ & $\begin{array}{l}\text { DATE OF } \\
\text { FIRBT } \\
\text { YOUNG }\end{array}$ & $\begin{array}{c}\text { NUMBER } \\
\text { OF } \\
d^{3} \emptyset\end{array}$ & $\begin{array}{c}\text { NUMBER } \\
\text { OF } \\
\wp 9\end{array}$ & $\begin{array}{c}\text { NUMBER } \\
\text { OF } \\
\text { GENERATION }\end{array}$ & $\begin{array}{l}\text { DATE OF } \\
\text { FIRST } \\
\text { YOUNG }\end{array}$ & $\begin{array}{c}\text { YUMBER } \\
\text { OF } \\
\text { व̛ }\end{array}$ & $\begin{array}{c}\text { NUMBER } \\
\text { OF } \\
9 \%\end{array}$ \\
\hline 1 & Mar. 28 & 13 & 43 & 10 & Apr. 15 & 26 & 22 \\
\hline 2 & 30 & 2 & 42 & 11 & 17 & 12 & 37 \\
\hline 3 & Apr. 2 & 14 & 31 & 12 & 19 & 26 & 19 \\
\hline 4 & 4 & 15 & 28 & 13 & 21 & 21 & 28 \\
\hline 5 & 6 & 21 & 19 & 14 & 23 & 24 & 19 \\
\hline 6 & 8 & 36 & 13 & 15 & 24 & 22 & 12 \\
\hline 7 & 10 & 15 & 28 & 16 & 26 & 16 & 16 \\
\hline 8 & 11 & 14 & 27 & 17 & 28 & 2 & 22 \\
\hline 9 & 13 & 21 & 31 & & & & \\
\hline \multicolumn{6}{|c|}{ 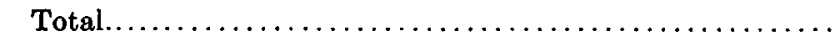 } & 300 & 437 \\
\hline
\end{tabular}

Percentage of $\sigma^{\pi} \%$

40.7 
TABLE 19

Showing number of eggs that hatched, out of 487 in lot $L_{3}$, figure 1

\begin{tabular}{|c|c|c|c|c|c|}
\hline DATE & $\begin{array}{l}\text { NUMBER } \\
\text { HATCEED }\end{array}$ & DATE & $\begin{array}{l}\text { NUMBER } \\
\text { HATCHED }\end{array}$ & DATE & $\begin{array}{l}\text { NUMBER } \\
\text { HATCHED }\end{array}$ \\
\hline Apr. 13 & 1 & Apr. 18 & 32 & Apr. $\quad 22$ & 3 \\
\hline 14 & 22 & 19 & 10 & $23-24$ & 0 \\
\hline 15 & 33 & 20 & 6 & 25 & 1 \\
\hline 16 & 53 & 21 & 1 & $26-30$ & 0 \\
\hline 17 & 29 & & & & \\
\hline \multicolumn{5}{|c|}{ Total $\ldots \ldots \ldots \ldots \ldots \ldots \ldots \ldots \ldots \ldots \ldots \ldots \ldots \ldots \ldots$} & 191 \\
\hline
\end{tabular}

Percentage of viable eggs.

39.2

TABLE 20

Showing details of parthenogenetic line $L_{3}$, in figure 1

\begin{tabular}{|c|c|c|c|c|c|c|c|}
\hline $\begin{array}{c}\text { NUMBER } \\
\text { OF } \\
\text { OENERATION }\end{array}$ & $\begin{array}{l}\text { DATE OF } \\
\text { FIRBT } \\
\text { YOUNG }\end{array}$ & $\begin{array}{c}\text { NUMBER } \\
\text { OF } \\
\sigma^{7} 9\end{array}$ & $\begin{array}{c}\text { NUMBER } \\
\text { OF } \\
\text { P }\end{array}$ & $\begin{array}{c}\text { NUMBER } \\
\text { OF } \\
\text { GENERATION }\end{array}$ & $\begin{array}{l}\text { DATE OF } \\
\text { FIRST } \\
\text { YOUNA }\end{array}$ & $\begin{array}{c}\text { NUMBER } \\
\text { OF } \\
\sigma^{2} \%\end{array}$ & $\begin{array}{c}\text { NUMBER } \\
\text { OF } \\
\text { \& } 9\end{array}$ \\
\hline 1 & May 12 & 5 & 22 & 4 & May 18 & 11 & 27 \\
\hline 2 & 14 & 6 & 7 & 5 & 21 & 19 & 19 \\
\hline 3 & 16 & 15 & 24 & & & & \\
\hline \multicolumn{6}{|l|}{ Total. } & 56 & 99 \\
\hline
\end{tabular}

Percentage of $\sigma^{7} q$

36.1

TABLE 21

Showing number of eggs that hatched, out of 728 in lot $H_{1}$, figure 1

\begin{tabular}{|c|c|c|c|c|c|}
\hline DATE & $\begin{array}{l}\text { NUMBER } \\
\text { HATCHED }\end{array}$ & DATE & $\begin{array}{r}\text { NUMBER } \\
\text { HATCHED }\end{array}$ & DATE & $\begin{array}{r}\text { NUMBER } \\
\text { HATCHED }\end{array}$ \\
\hline Jan. 30 & 2 & Feb. 7 & 42 & Feb. & 0 \\
\hline 31 & 7 & 8 & 32 & 16 & 3 \\
\hline Feb. 1 & 28 & 9 & 79 & 17 & 1 \\
\hline 2 & 19 & 10 & 38 & $18-21$ & 0 \\
\hline 3 & 2 & 11 & 29 & 22 & 1 \\
\hline 4 & 11 & 12 & 57 & $23-25$ & 0 \\
\hline 5 & 4 & 13 & 11 & 26 & 1 \\
\hline 6 & 12 & 14 & 2 & Feb. 27-Mar. 1 & 0 \\
\hline \multicolumn{5}{|c|}{ Total $\ldots \ldots \ldots \ldots \ldots \ldots \ldots \ldots \ldots \ldots \ldots \ldots \ldots \ldots \ldots$} & 381 \\
\hline
\end{tabular}

Percentage of viable eggs.

52.3 
Effect of selection for high viability in a hybrid line

Let us now turn to the high viability series, beginning with the parthenogenetic line in $(C \times D) \times(C \times D)$, whose parent hatched 11 out of 15 eggs (viability 73.3 per cent).

$H_{1}$. Females of the parthenogenetic line bred from a highly viable family in $(C \times D) \times(C \times D)$ were paired with males of the same line January 20 to 28,1912 . From 53 such matings, 728 fertilized eggs were obtained. By March 1, 381 of these, or 52.3 per cent, had hatched (table 21). Of the low viability lot of eggs, $L_{2}$, there hatched at the same time but 28.9 per cent.

One of the above 53 females laid $16 \mathrm{eggs}$, of which 12 , or 75 per cent, hatched. From the first of her twelve daughters the parthenogenetic line designated $H_{1}$ was reared. It included but 18.9 per cent of male-producers (table 22).

$H_{2}$. Females of the parthenogenetic line $H_{1}$ were paired with males of the same line, February 17 to March 8, 1912. From 43 such females were obtained 583 eggs, of which 288 , or 49.3 per cent, hatched before April 10 (table 23). The low viability lot of eggs, $L_{2}$, corresponding to the high viability lot $H_{2}$, hatched but 35.3 per cent. It should be noted that these two lots of eggs were not on the whole hatching simultaneously. Whereas the bulk of the eggs in $L_{2}$ hatched at the end of February, the lot $H_{2}$ reached its maximum about March 20. This was unavoidable owing to the fact that the scarcity of male-producers in

TABLE 22

Showing details of parthenogenetic line $H_{1}$, in figure 1

\begin{tabular}{|c|c|c|c|c|c|c|c|}
\hline $\begin{array}{c}\text { NUMBER } \\
\text { OF } \\
\text { OENERATION }\end{array}$ & $\begin{array}{l}\text { DATE OF } \\
\text { FIRST } \\
\text { YOUNG }\end{array}$ & $\begin{array}{c}\text { NUMBER } \\
\text { OF } \\
\sigma^{7} \%\end{array}$ & $\begin{array}{c}\text { NUMBER } \\
\text { OF } \\
9 \%\end{array}$ & $\begin{array}{c}\text { NUMBER } \\
\text { OF } \\
\text { GENERATION }\end{array}$ & $\begin{array}{l}\text { DATE OF } \\
\text { FIRST } \\
\text { YOUNG }\end{array}$ & $\begin{array}{c}\text { NUMBER } \\
\text { OF } \\
\sigma^{7} \%\end{array}$ & $\begin{array}{c}\text { NUMBER } \\
\text { OF } \\
\wp \%\end{array}$ \\
\hline 1 & Feb. 18 & 7 & 44 & 4 & Feb. 27 & 16 & 36 \\
\hline 2 & 21 & 3 & 37 & 5 & 29 & 10 & 34 \\
\hline \multirow[t]{3}{*}{3} & 24 & 3 & 36 & 6 & Mar. 3 & 20 & 25 \\
\hline & 25 & 3 & 26 & 7 & 5 & $6^{1}$ & $29^{1}$ \\
\hline & 26 & 4 & 24 & 8 & 7 & $0^{1}$ & $16^{1}$ \\
\hline \multicolumn{6}{|l|}{ Total. } & 72 & 307 \\
\hline
\end{tabular}

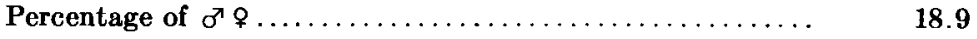

${ }^{1}$ Remainder of family not recorded. 
the high viability parthenogenetic line prevented the fertilization of a sufficient number of eggs. The fluctuation of the viability, which will be apparent later, may be due to the fact that the two lots did not hatch simultaneously.

Of the 43 females that laid the eggs in lot $H_{2}$, one laid $13 \mathrm{eggs}$, of which 10, or 76.9 per cent, hatched. From the first of her

TABLE 23

Showing number of fertilized eggs that hatched, out of 585 in lot $\mathrm{H}_{2}$, figure 1

\begin{tabular}{|c|c|c|c|c|c|c|}
\hline \multicolumn{2}{|l|}{ DATE } & \multirow{2}{*}{$\begin{array}{c}\begin{array}{c}\text { NUMBER } \\
\text { HATCHED }\end{array} \\
3\end{array}$} & DATE & $\begin{array}{l}\text { NUMBER } \\
\text { HATCHED }\end{array}$ & DATE & $\begin{array}{l}\text { NUMBER } \\
\text { FATCHED }\end{array}$ \\
\hline Feb. & 28 & & Mar. 13 & 12 & Mar. 25 & 9 \\
\hline & 29 & 5 & .14 & 4 & 26 & 2 \\
\hline Mar. & 1 & 3 & 15 & 3 & 27 & 3 \\
\hline & 2 & 1 & 16 & 5 & 28 & 1 \\
\hline & 3 & 0 & 17 & 6 & 29 & $\mathbf{0}$ \\
\hline & 4 & 1 & 18 & 7 & 30 & 2 \\
\hline & 5 & 1 & 19 & 21 & 31 & 0 \\
\hline & $6-8$ & 0 & 20 & 34 & Apr. & 2 \\
\hline & 9 & 2 & 21 & 38 & $3-3$ & 0 \\
\hline & 10 & 0 & 22 & 13 & 4 & 1 \\
\hline & 11 & 1 & 23 & 39 & $5-10$ & 0 \\
\hline & 12 & 0 & 24 & 69 & & \\
\hline \multicolumn{6}{|c|}{ 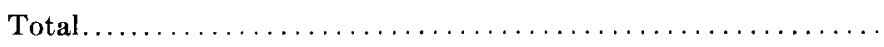 } & 288 \\
\hline
\end{tabular}

Percentage of viable eggs.

49.3

TABLE 24

Showing details of parthenogenetic line $H_{2}$, in figure 1

\begin{tabular}{|c|c|c|c|c|c|c|c|}
\hline $\begin{array}{c}\text { NUMBER } \\
\text { OF } \\
\text { GENERATION }\end{array}$ & $\begin{array}{l}\text { DATE OF } \\
\text { FIRST } \\
\text { YOUNG }\end{array}$ & $\begin{array}{c}\text { NUMBER } \\
\text { OF } \\
0^{7} \%\end{array}$ & $\begin{array}{c}\text { NCMBER } \\
\text { OF } \\
\wp \%\end{array}$ & $\begin{array}{c}\text { NUMBER } \\
\text { OF } \\
\text { GENERATION }\end{array}$ & $\begin{array}{c}\text { DATE OF } \\
\text { FIRST } \\
\text { YOUNG }\end{array}$ & $\begin{array}{c}\text { NUMBER } \\
\text { OF } \\
\sigma^{\prime} Q\end{array}$ & $\begin{array}{c}\text { NUMBER } \\
\text { OF } \\
\wp \%\end{array}$ \\
\hline 1 & Mar. 22 & 3 & 19 & 6 & Apr. 3 & 12 & 32 \\
\hline 2 & 25 & 19 & 26 & 7 & 5 & 7 & 39 \\
\hline \multirow[t]{2}{*}{3} & 28 & 11 & 25 & 8 & 7 & 15 & 34 \\
\hline & 29 & 0 & 43 & 9 & 9 & 7 & 33 \\
\hline 4 & 30 & 7 & 48 & 10 & 11 & 0 & 9 \\
\hline 5 & Apr. 1 & 4 & 27 & 11 & 13 & 5 & 19 \\
\hline \multicolumn{6}{|c|}{ 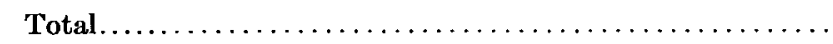 } & 90 & 354 \\
\hline
\end{tabular}

Percentage of $o^{7} 9 \ldots \ldots \ldots \ldots \ldots \ldots \ldots \ldots \ldots \ldots \ldots, \quad 20.2$ 
ten daughters was bred the parthenogenetic line $H_{2}$ (table 24). It included 20.2 per cent of male-producers.

$H_{3}$. Females of the parthenogenetic line $H_{2}$ were paired with males of the same line March 29 to April 7, 1912. From 42 such females, 640 eggs were obtained, of which 407 , or 63.5 per cent, hatched before April 30 (table 25). The low viability lot $L_{3}$ hatched, at about the same time, only 39.2 per cent.

TABLE 25

Showing number of fertilized eggs that hatched, out of 640 in lot $H_{3}$, figure 1

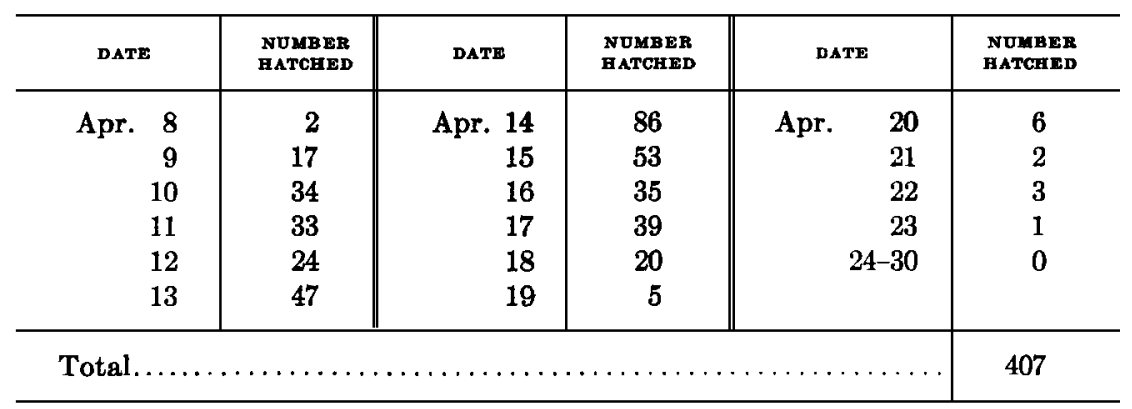

Percentage of viable eggs.

63.5

From the 42 females that laid the eggs in lot $H_{3}$, two were selected for further breeding. One laid $16 \mathrm{eggs}$, of which but 7, or 43.7 per cent, hatched; the other laid $21 \mathrm{eggs,}$ of which 17, or 80.9 per cent, hatched. From the first daughter of each was bred a parthenogenetic line, as given in table 26 . The purpose was to test the effect of selection within the high viability series, the results of which are described later. The first of these lines included 10.0 per cent, the second 11.1 per cent of male-producers.

The percentage viability of the eggs in lots $L_{1}, L_{2}$, and $L_{3}$ were $28.9,35.3$, and 39.2 , respectively; in lots $H_{1}, H_{2}$, and $H_{3}$, it was $52.3,49.3$, and 63.5 , respectively. The high viability lots were consistently more viable than the lots selected for low viability. With the exception of the second lots, the difference between the two lots is nearly constant; and this exception is probably due to the fact that $L_{2}$ and $H_{2}$ were not hatched at the 
same time, and hence not under the same conditions. Selection affected viability, but this effect was all in the first selection, and further selection did not increase the difference in viability.

\section{Effect of crossing on viability in two lines made different by selection}

Whether selection produced a permanent difference, or whether the difference was maintained only by continuous selection, was determined by the remaining experiments. First among these were reciprocal crosses between the parthenogenetic lines in $L_{2}$ and $H_{2}$.

$L_{2} \times H_{2}$. Females of the parthenogenetic line $L_{2}$ (see fig. 1) were mated with males of the line $H_{2}$ April 11 to 19, 1912. From 36 such females were obtained 427 eggs, of which 245 , or 57.3 per cent, hatched before May 6, as in table 27.

\section{TABLE 26}

Showing details of two parthenogenetic lines in $H_{3}$, figure 1 , one derived from $a$ family in which only 43.7 per cent of the fertilized eggs hatched, the other from a family in which 80.9 per cent of the eggs hatched.

\begin{tabular}{|c|c|c|c|c|c|c|c|}
\hline \multicolumn{4}{|c|}{ LOW VIABILITY } & \multicolumn{4}{|c|}{ HIOH VIABILITY } \\
\hline $\begin{array}{c}\text { NUMBER } \\
\text { OF } \\
\text { GENERATION }\end{array}$ & $\begin{array}{l}\text { DATE OF } \\
\text { FIRAT } \\
\text { YOUNG }\end{array}$ & $\begin{array}{c}\text { NUMBER } \\
\text { OF } \\
\sigma^{7} q\end{array}$ & $\begin{array}{c}\text { NUMBER } \\
\text { OF } \\
\& \%\end{array}$ & $\begin{array}{c}\text { NUMBER } \\
\text { OF } \\
\text { GENERATION }\end{array}$ & $\begin{array}{l}\text { DATE OF } \\
\text { FIRAT } \\
\text { YOUNG }\end{array}$ & $\begin{array}{c}\text { NUMBER } \\
\text { OF } \\
\sigma^{\top} \%\end{array}$ & $\begin{array}{c}\text { NUMBER } \\
\text { OF } \\
\text { \% } \%\end{array}$ \\
\hline 1 & May 2 & 0 & 28 & 1 & May 2 & 2 & 17 \\
\hline 2 & 4 & 0 & 50 & 2 & 4 & 1 & 53 \\
\hline 3 & 6 & 0 & 42 & 3 & 6 & 0 & 25 \\
\hline 4 & 7 & 1 & 33 & 4 & 7 & 9 & 34 \\
\hline 5 & 9 & 3 & 36 & 5 & 9 & 7 & 18 \\
\hline \multirow[t]{2}{*}{6} & 11 & 4 & 39 & 6 & 11 & 3 & 18 \\
\hline & 12 & 15 & 50 & 7 & 13 & 3 & 25 \\
\hline 7 & 12 & 8 & 15 & 8 & 15 & 0 & 27 \\
\hline 8 & 15 & 1 & 31 & 9 & 17 & 13 & 26 \\
\hline 9 & 17 & 7 & 28 & 10 & 19 & 1 & 35 \\
\hline 10 & 19 & 6 & 39 & 11 & 21 & 0 & 33 \\
\hline 11 & 21 & 1 & 22 & & & & \\
\hline \multicolumn{2}{|c|}{ Total........... } & 46 & 413 & \multicolumn{2}{|c|}{ Total............ } & 39 & 311 \\
\hline \multicolumn{4}{|c|}{ Percentage of $\sigma^{7} \% \ldots$} & \multicolumn{4}{|c|}{ Percentage of $\sigma^{7} q \ldots . \quad 11.1$} \\
\hline
\end{tabular}


$H_{2} \times L_{2}$. Fèmales of the parthenogenetic line $H_{2}$ were mated with males of the line $L_{2}$ April 7 to 15, 1912. From 30 such females, 294 eggs were obtained. Of these, 203, or 69.0 per cent, hatched before May 6 (table 28).

These reciprocal crosses bear precisely the same relation to each other and to their parents as do the reciprocal crosses $C \times D$ and $D \times C$. The reciprocals are unequal, that one having the higher viability whose mother belonged to the high viability line. In both cases, the cross whose mother came from the high viability line $\left(C \times D\right.$ and $\left.H_{2} \times L_{2}\right)$ possessed greater viability than either parent line.

TABLE 27

Showing number of fertilized eggs that hatched, out of 427 in lot $L_{2} \times H_{2}$, in figure 1

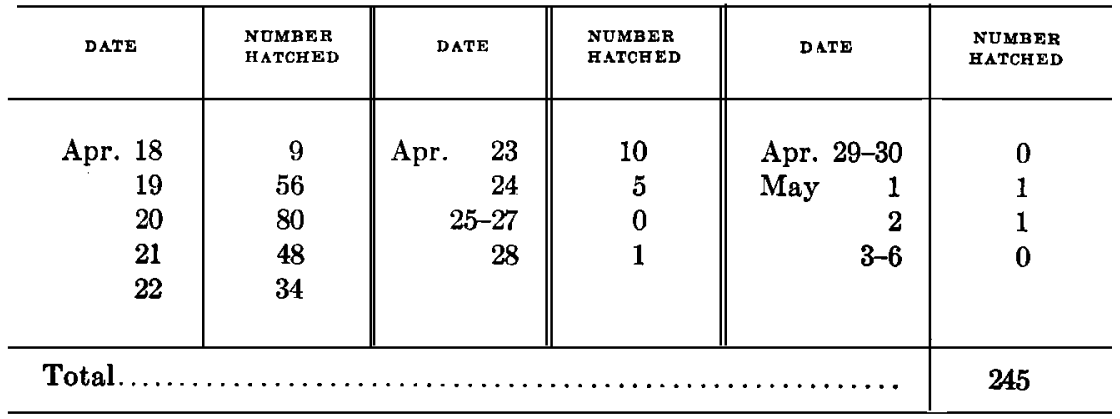

Percentage of viable eggs.

57.3

TABLE 28

Shouing number of fertilized eggs that hatched, out of 294 in lot $H_{2} \times L_{2}$, in figure 1

\begin{tabular}{|c|c|c|c|c|c|}
\hline DATE & $\begin{array}{r}\text { NCMBER } \\
\text { HATCHED }\end{array}$ & DATE & $\begin{array}{r}\text { NUMBER } \\
\text { HATCHE.D }\end{array}$ & DATE & $\begin{array}{l}\text { NUMBER } \\
\text { HATCHED }\end{array}$ \\
\hline Apr. 16 & 1 & Apr. 22 & 35 & Apr. & 4 \\
\hline 17 & 0 & 23 & 11 & 28 & 3 \\
\hline 18 & 1 & 24 & 4 & $29-30$ & 0 \\
\hline 19 & 10 & 25 & 10 & May & 3 \\
\hline 20 & 57 & 26 & 3 & $2-6$ & 0 \\
\hline 21 & 61 & & & & \\
\hline \multicolumn{5}{|c|}{ 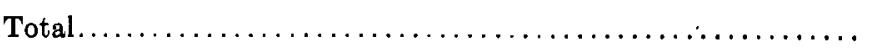 } & 203 \\
\hline \multicolumn{5}{|c|}{ Percentage of viable eggs. $\ldots \ldots \ldots \ldots \ldots \ldots \ldots \ldots \ldots \ldots \ldots$} & 69.0 \\
\hline
\end{tabular}


Effect of selection for high and low viability in the low viability series (repeatedly inbred)

$L_{4}$. Females from the parthenogenetic line $L_{3}$, whose parent was selected at random without reference to viability, were mated with males of the same line May 19 to 23, 1912. From 38 such females were obtained $241 \mathrm{eggs}$, of which 53, or 21.9 per cent, hatched before June 7 (table 29).

Twelve of the above 38 females were kept isolated and the hatching of their eggs recorded separately. In the least viable family, $1 \mathrm{egg}$ in 12, or 8.3 per cent, hatched; in the most viable, 4 out of 11, or 36.3 per cent, hatched. From the first daughter in each family a parthenogenetic line was reared (table 30). The low viability line included 37.5 per cent of male-producers, the high viability line 13.6 per cent.

$L$ from $L$. Females of the parthenogenetic line in $L_{4}$ bred from a low viability family were mated with males of the same line June 11 to 13, 1912. From 26 such females 223 eggs were obtained, of which 74, or 33.1 per cent, hatched prior to July 14 (table 31).

$H$ from $L$. Females of the high viability line (selected for high viability from low viability eggs) in $L_{4}$ were mated with males of the same line June 15 and 16, 1912. From 12 such females 74 eggs were obtained, of which 24 , or 32.4 per cent, hatched prior to July 14 (table 32).

TABLE 29

Showing number of fertilized eggs that hatched, out of 241 in lot $L_{4}$, figure 1

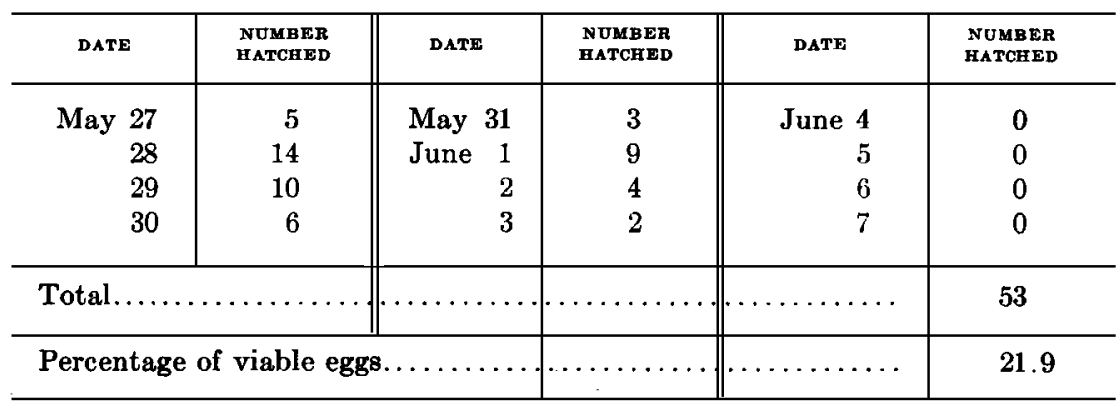


TABLE 30

Showing details of two parthenogenetic lines in $L_{4}$, figure 1 , one line being reared from a family in which few eggs hatched, the other from a family in which relatively many eggs hatched

\begin{tabular}{|c|c|c|c|c|c|c|c|c|}
\hline \multicolumn{5}{|c|}{ Low viabILIT } & & \multicolumn{3}{|c|}{ High viabinity } \\
\hline $\begin{array}{l}\text { NUMBER OF } \\
\text { GENGRATION }\end{array}$ & $\begin{array}{l}\text { DATE } \\
\text { FIRS } \\
\text { YOUN }\end{array}$ & & $\begin{array}{l}\text { No. or } \\
\text { o's }\end{array}$ & $\begin{array}{c}\text { NUMBER } \\
\stackrel{9}{q}\end{array}$ & $\begin{array}{l}\text { NUMBER OF } \\
\text { GENBRATION }\end{array}$ & $\begin{array}{c}\text { DATE OI } \\
\text { FIRST } \\
\text { YOUNG }\end{array}$ & $\begin{array}{c}\text { NUMBER } \\
\text { o' }^{\prime} q\end{array}$ & OF $\begin{array}{c}\text { NUMBER OF } \\
\& \%\end{array}$ \\
\hline 1 & June & 3 & 5 & 31 & 1 & June & 0 & 7 \\
\hline \multirow[t]{2}{*}{2} & & 4 & 0 & 6 & 2 & & 0 & 6 \\
\hline & & 4 & 0 & 4 & & & $\mathbf{0}$ & 16 \\
\hline \multirow[t]{2}{*}{3} & & 6 & 12 & 28 & 3 & & 2 & 33 \\
\hline & & 6 & 0 & 8 & 4 & 1 & 3 & 24 \\
\hline 4 & & 10 & 18 & 15 & 5 & 1 & 1 & 30 \\
\hline 5 & & 12 & 18 & 10 & 6 & 1 & 9 & 19 \\
\hline \multirow[t]{4}{*}{6} & & 14 & 15 & 11 & 7 & 1 & 4 & 24 \\
\hline & & & & & 8 & 1 & 7 & 19 \\
\hline & & & & & 9 & 2 & 0 & 7 \\
\hline & & & & & & 2 & 7 & 24 \\
\hline \multicolumn{3}{|c|}{ Total........... } & 68 & 113 & \multicolumn{2}{|l|}{ Total. } & 33 & 209 \\
\hline \multicolumn{5}{|c|}{ Percentage of $\sigma \% \ldots$} & \multicolumn{2}{|c|}{ Percentage of $\sigma^{7} q$} & \multicolumn{2}{|c|}{13.6} \\
\hline
\end{tabular}

TABLE 31

Showing number of eggs that hatched, out of 223 in lot ( $L$ from $L)$, figure 1

\begin{tabular}{|c|c|c|c|c|c|}
\hline DATE & $\begin{array}{l}\text { NUMBER } \\
\text { HATCEED }\end{array}$ & DATE & $\begin{array}{l}\text { NUMBER } \\
\text { HATCHED }\end{array}$ & DATE & $\begin{array}{l}\text { NUMBER } \\
\text { HATCHED }\end{array}$ \\
\hline June 20 & 1 & June 25 & 9 & June 29 & 2 \\
\hline 21 & 11 & 26 & 4 & 30 & 1 \\
\hline 22 & 15 & 27 & 0 & July 1 & 2 \\
\hline 23 & 18 & 28 & 1 & $2-14$ & 0 \\
\hline 24 & 10 & & & & \\
\hline \multicolumn{5}{|c|}{ Total $\ldots \ldots \ldots \ldots \ldots \ldots \ldots \ldots \ldots \ldots \ldots \ldots \ldots \ldots \ldots$} & 74 \\
\hline
\end{tabular}

Percentage of viable eggs. 
Since $L$ from $L$, and $H$ from $L$ show almost precisely the same viability, selection for high and low viability within the low viability lot was entirely ineffective.

Effect of selection for high and low viability in the high viability series (repeatedly inbred)

$L_{1}$ from $H$. Females of the parthenogenetic line bred from a low viability family in $\mathrm{H}_{3}$ were mated with males of the same line May 13 to 23, 1912. From 18 such females were obtained 161 eggs, of which 94 , or 58.3 per cent, hatched prior to June 5 (table 33).

One of these 18 females laid nine eggs, of which only one hatched (11.1 per cent of viable eggs). From that one a parthenogenetic line was reared, as in table 34 , including 16.1 per cent of inale-producers.

TABLE 32

Showing number of fertilized eggs that hatched, out of 74 in lot (H from L), figure 1

\begin{tabular}{|c|c|c|c|c|c|}
\hline DATE & $\begin{array}{l}\text { NUMBER } \\
\text { HATCHED }\end{array}$ & DATE & $\begin{array}{r}\text { NUMBER } \\
\text { HATCHED }\end{array}$ & DATE & $\begin{array}{l}\text { NUMBER } \\
\text { FATCHED }\end{array}$ \\
\hline June 24 & 2 & June 27 & 3 & June 30 & 1 \\
\hline 25 & 8 & 28 & 2 & July & 4 \\
\hline 26 & 2 & 29 & 2 & $2-14$ & 0 \\
\hline \multicolumn{5}{|c|}{ 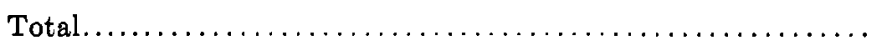 } & 24 \\
\hline
\end{tabular}

Percentage of viable eggs. 32.4

TABLE 33

Showing number of eggs that hatched, out of 161 in lot $\left(L_{1}\right.$ from $\left.H\right)$, figure 1

\begin{tabular}{|c|c|c|c|c|c|}
\hline DATE & $\begin{array}{l}\text { NUMBER } \\
\text { HATCHED }\end{array}$ & DATE & $\begin{array}{l}\text { NUMBER } \\
\text { HATCEED }\end{array}$ & DATE & $\begin{array}{l}\text { NUMBER } \\
\text { HATCHED }\end{array}$ \\
\hline $\begin{array}{r}\text { May } 22 \\
23 \\
24 \\
25 \\
26\end{array}$ & $\begin{array}{r}1 \\
7 \\
13 \\
7 \\
10\end{array}$ & $\begin{array}{r}\text { May } 27 \\
28 \\
29 \\
30 \\
31\end{array}$ & $\begin{array}{r}30 \\
14 \\
2 \\
5 \\
1\end{array}$ & $\begin{array}{r}\text { June } 1 \\
\mathbf{2} \\
\mathbf{3} \\
\mathbf{4} \\
\mathbf{5}\end{array}$ & $\begin{array}{l}3 \\
1 \\
0 \\
0 \\
0\end{array}$ \\
\hline \multicolumn{5}{|c|}{ 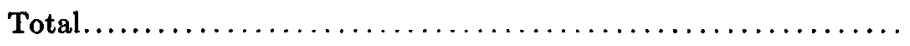 } & 94 \\
\hline \multicolumn{5}{|c|}{ Percentage of viable eggs $\ldots \ldots \ldots \ldots \ldots \ldots \ldots \ldots \ldots \ldots \ldots$} & 58.3 \\
\hline
\end{tabular}


$H_{1}$ from $H$. Females of the parthenogenetic line bred from a high viability family in $H_{3}$ were mated with males of the same line May 11 to 20, 1912. From 23 such females were obtained 259 eggs, of which 125 , or 48.2 per cent, hatched prior to June 19 (table 35).

Comparison of $L_{1}$ from $H$ with $H_{1}$ from $H$ shows that a single selection for low viability within the high viability series was entirely ineffective.

TABLE 34

Showing details of parthenogenetic line in $\left(L_{1}\right.$ from $\left.H\right)$, figure 1

\begin{tabular}{|c|c|c|c|c|c|c|c|}
\hline $\begin{array}{c}\text { NUMBER } \\
\text { OF } \\
\text { GENERATION }\end{array}$ & $\begin{array}{l}\text { DATE OF } \\
\text { FIRAT } \\
\text { YOUNG }\end{array}$ & $\begin{array}{c}\text { NUMBER } \\
\text { OF } \\
\text { व’ } ?\end{array}$ & $\begin{array}{c}\text { NOMBER } \\
\text { OF } \\
\varnothing \varnothing\end{array}$ & $\begin{array}{c}\text { NOMBER } \\
\text { OF } \\
\text { GENERATION }\end{array}$ & $\begin{array}{l}\text { DATE OF } \\
\text { FIRST } \\
\text { YOUNG }\end{array}$ & $\begin{array}{c}\text { NUMBER } \\
\text { OF } \\
\sigma^{\prime} \%\end{array}$ & $\begin{array}{c}\text { NUMBER } \\
\text { OF } \\
\varnothing \varnothing\end{array}$ \\
\hline 1 & May 30 & 1 & 26 & 7 & June 11 & 1 & 26 \\
\hline 2 & 31 & 4 & 18 & 8 & 13 & 6 & 26 \\
\hline 3 & June 3 & 9 & 30 & 9 & 15 & 6 & 14 \\
\hline 4 & 4 & 8 & 36 & 10 & 16 & 0 & 30 \\
\hline 5 & 7 & 5 & 34 & 11 & 18 & 10 & 18 \\
\hline 6 & 9 & 1 & 36 & & 18 & 9 & 18 \\
\hline \multicolumn{6}{|l|}{ Total. } & 60 & 312 \\
\hline \multicolumn{8}{|c|}{ 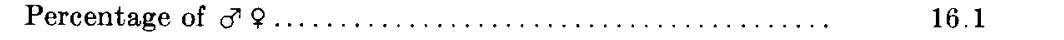 } \\
\hline
\end{tabular}

TABLE 35

Showing number of fertilized eggs that hatched, out of 259 in lot $\left(H_{1}\right.$ from $\left.H\right)$,

figure 1

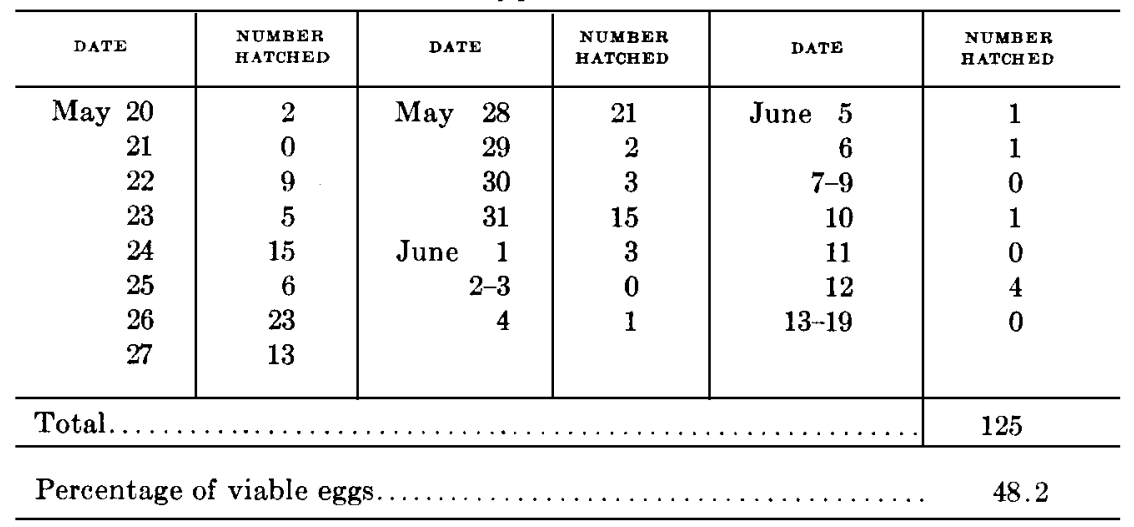


One of the 23 families in lot $H_{1}$ from $H$ laid 14 eggs, of which 11, or 78.5 per cent, hatched. From the first of her 11 daughters a parthenogenetic line was reared, as in table 36, including 35.8 per cent of male-producers.

$L_{2}$ from $H$. Females of the parthenogenetic line $L_{1}$ from $H$ were mated with males of the same line June 9 to $17,1912$. From eight such females were obtained 65 eggs, of which 36 , or 55.3 per cent, hatched prior to July 1 (table 37).

$\mathrm{H}_{2}$ from $H$. Females of the parthenogenetic line $H_{1}$ from $H$ were mated with males of the same line June 8 to $13,1912$. From 23 such females were obtained 164 eggs, of which 92, or 56.0 per cent, hatched prior to July 14 (table 38).

Comparison of $L_{2}$ from $H$ with $H_{2}$ from $H$ indicates that a second selection for high and low viability within the high viability series had no effect.

TABLE 36

Showing details of parthenogenetic line in $\left(H_{1}\right.$ from $\left.H\right)$, figure 1

\begin{tabular}{|c|c|c|c|c|c|c|c|c|}
\hline $\begin{array}{c}\text { NUMBER } \\
\text { OF } \\
\text { GENERATION }\end{array}$ & $\begin{array}{l}\text { DATE OF } \\
\text { FIRST } \\
\text { YOUNG }\end{array}$ & $\begin{array}{c}\text { NUMBER } \\
\text { OF } \\
O^{\prime} 9\end{array}$ & $\begin{array}{c}\text { NUMBER } \\
\text { OF } \\
q \%\end{array}$ & $\begin{array}{c}\text { NUMBER } \\
\text { OF } \\
\text { GENEHATION }\end{array}$ & $\begin{array}{l}\text { DATES O } \\
\text { FIRST } \\
\text { YOUN }\end{array}$ & & $\begin{array}{c}\text { NOMBER } \\
\text { OF } \\
\sigma^{2} ?\end{array}$ & $\begin{array}{c}\text { NUMBER } \\
\text { OF } \\
8 \%\end{array}$ \\
\hline 1 & May 29 & 0 & 13 & 5 & June & 7 & 11 & 16 \\
\hline 2 & & 0 & 9 & 6 & & 9 & 0 & 3 \\
\hline 3 & June 3 & 1 & 4 & & & 11 & 0 & 2 \\
\hline 4 & 4 & 14 & 28 & 7 & & 11 & 27 & 20 \\
\hline \multicolumn{7}{|l|}{ Total. } & 53 & 95 \\
\hline \multicolumn{9}{|c|}{ 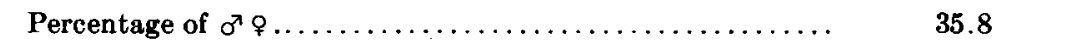 } \\
\hline
\end{tabular}

TABLE 37

Showing number of fertilized eggs that hatched, out of 65 in lot $\left(L_{2}\right.$ from $\left.H\right)$, figure 1

\begin{tabular}{|c|c|c|c|c|c|}
\hline DATE & $\begin{array}{r}\text { NUMBER } \\
\text { HATCHED }\end{array}$ & DATE & $\begin{array}{r}\text { NUMBER } \\
\text { HATCHED }\end{array}$ & DATE & $\begin{array}{r}\text { NUMBER } \\
\text { HATCHED }\end{array}$ \\
\hline June 18 & 4 & June 21 & 5 & June 24 & 1 \\
\hline 19 & 11 & 22 & 4 & 25 & 1 \\
\hline 20 & 7 & 23 & 3 & June 26-July 1 & 0 \\
\hline \multicolumn{5}{|c|}{ 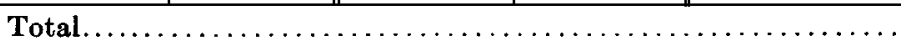 } & 36 \\
\hline
\end{tabular}

Percentage of viable eggs. 
TABLE 38

Showing number of fertilized eggs that hatched, out of 164 in lot $\left(\mathrm{H}_{2}\right.$ from $\left.\mathrm{H}\right)$, figure 1

\begin{tabular}{r|r|r|r||r|r}
\hline \multicolumn{1}{c|}{ DATE } & $\begin{array}{c}\text { NUMBER } \\
\text { HATCHED }\end{array}$ & \multicolumn{1}{|c||}{ DATE } & $\begin{array}{c}\text { NUMBER } \\
\text { HATCHED }\end{array}$ & DATE & $\begin{array}{c}\text { NUMBER } \\
\text { HATCHED }\end{array}$ \\
\hline June 17 & 1 & June 23 & 7 & June 28 & 3 \\
18 & 26 & 24 & 5 & 29 & 2 \\
19 & 12 & 25 & 6 & 30 & 2 \\
20 & 8 & 26 & 2 & July 1 & 6 \\
21 & 4 & 27 & 2 & $2-14$ & 0 \\
22 & 6 & & & \\
\hline
\end{tabular}

\section{RESULTS OF THE EXPERIMENTS}

The results of the experiments may be stated under three heads: (1) The effect of crossing on the viability of eggs and on the variability of the duration of the egg stage; (2) effect of selection on viability of eggs in a hybrid line and in relatively 'pure' lines; and (3) inheritance of the sex-ratio. Figure 2 will aid in presenting these results.

1. The effect of crossing. Viability of eggs. This was tested twice in the experiments: once in reciprocal crosses between lines $C$ and $D$, which were found, already distinctly different in viability, in previous experiments, and again in reciprocals between $L_{2}$ and $H_{2}$, which had been made to differ in viability by means of selection. In both cases the average viability of the two lots of $F_{1}$ fertilized eggs (for instance, $C \times D$ and $D \times C$ ) was considerably greater than the average viability of the inbred eggs of the two lines crossed. In both casses, the two reciprocal crosses were unequal, that one being most viable which had the high viability mother, and conversely. These results indicate that $L_{2}$ and $\mathrm{H}_{2}$, made different by selection, differed from one another in precisely the same way as $\operatorname{did} C$ and $D$, which were found different in previous experiments.

The inequality of the reciprocal crosses lasted, however, only through the egg stage. For when parthenogenetic lines were 


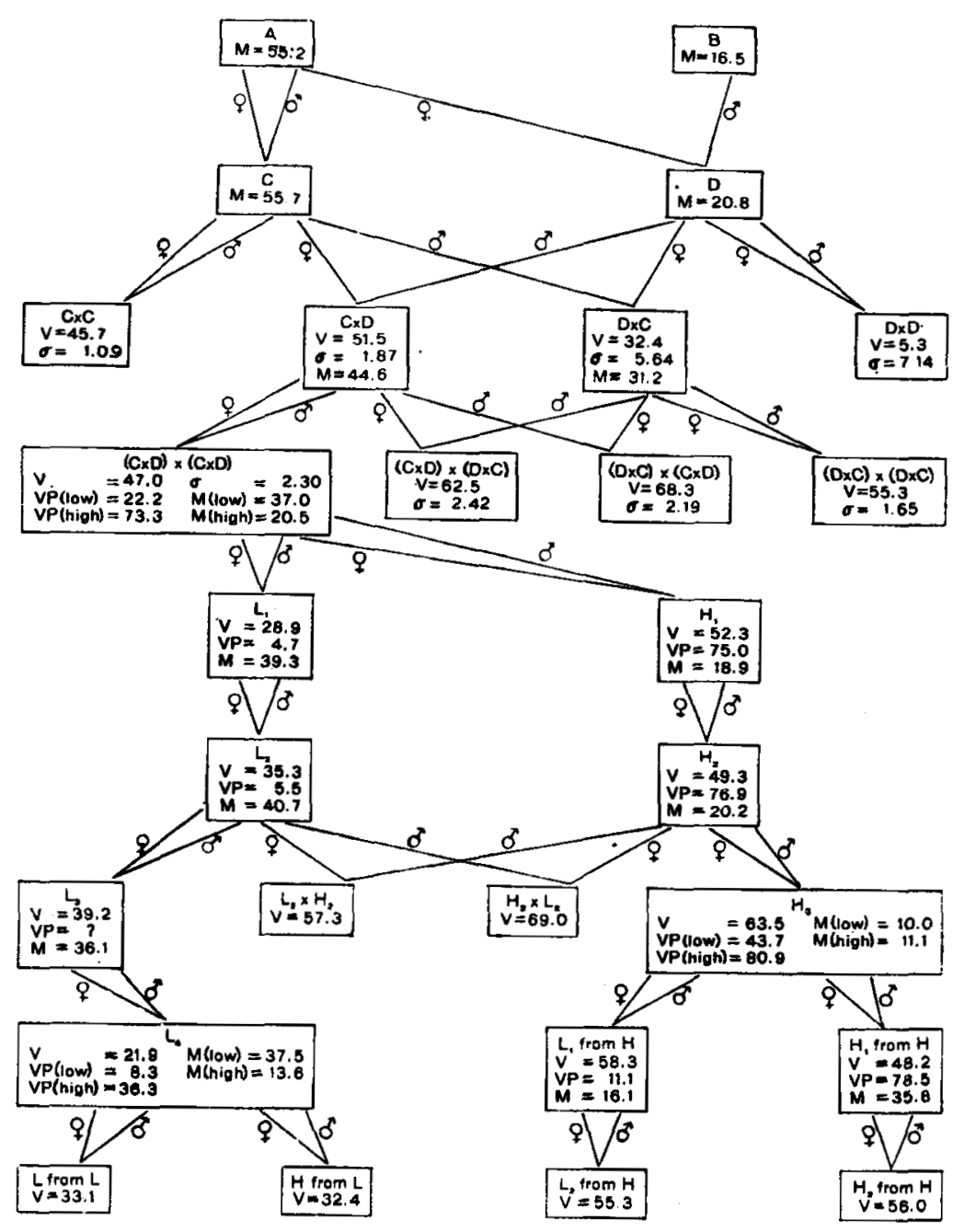

Fig. 2 Diagram showing results of all experiments described in text (see also fig. 1). $M=$ percentage of male-producers in parthenogenetic line. $V$ $=$ percentage of viable fertilized eggs. $\mathrm{VP}=$ percentage viability in family of fertilized eggs from which parthenogenetic line was derived, $\sigma=$ standard deviation of duration of egg stage.

reared from the fertilized eggs in $C \times D$ and $D \times C$, and these lines were in turn inbred and reciprocally crossed, the following result appeared: the two lots of inbred eggs were approximately 
equal in viability, and the two reciprocal crosses were approximately equal.

Variability of the duration of the egg stage. The effect of crossing on the variability of the duration of the egg stage was tested in two successive generations, beginning with a cross between lines $C$ and $D$. The standard deviation of the hatching time for inbred eggs of these two lines were widely different (1.09 and 7.14 respectively). The standard deviations of the two reciprocal crosses were intermediate between those of the inbred eggs, but were very unequal (1.87 and 5.64); each cross was nearer its female parent, in point of variability of hatching time.

This inequality existed only in the egg stage, however, for when the two reciprocal crosses $(C \times D$ and $D \times C)$ were in turn inbred and reciprocally crossed, the variability of hatching time did not materially differ in the four lots of eggs (standard deviation being $2.30,2.42,2.19$ and 1.65 , respectively).

2. The effect of selection on viability of eggs. In hybrid lines. In the lot of eggs designated $(C \times D) \times(C \times D)$, which were only once inbred from an $F_{1}$ (and hence hybrid) parthenogenetic line, selection was made for families of high and low viability, respectively. From the selected eggs, parthenogenetic lines were reared, and among their inbred eggs, selection for families of high and low viability was again made. Three successive selections resulted in an average difference of about 21 per cent in the viability of the eggs; but practically all this difference was produced by the first selection, and was not thereafter appreciably increased.

Selection in relatively 'pure' lines. Three successive inbreedings, as described above, must have changed many heterozygous characters to the homozygous condition, if random segregation and recombination occur; hence the parthenogenetic lines $L_{3}$ and $\mathrm{H}_{3}$ must have been relatively 'pure,' that is, homozygous. Was the difference in viability between $L_{3}$ and $H_{3}$ fertilized eggs a permanent product of selection, or had it been maintained only by continued selection?

Random selection from $L_{3}$, without reference to the viability of the parents, resulted in a lowered viability in $L_{4}$. This may 
have been due to external conditions; at any rate, viability did not increase when selection for low viability was discontinued. Selection was then made for high and low viability in this "random" lot of eggs, but the results, as shown in $L$ from $L$ and $H$ from $L$, figure 2, show that selection was wholly ineffective. The low viability eggs were permanently of low viability, not kept low by continued selection; selection within the low viability series was of no avail.

In like manner, selection for high and low viability among the high viability families of $H_{3}$ (cf. $L_{1}$ from $H$, and $H_{1}$ from $H$; also, $L_{2}$ from $H$, and $H_{2}$ from $H$ ) did not alter the viability in the direction of selection. The high viability eggs were inherently of high viability, not maintained so by selection.

3. Inheritance of the sex-ratio. In every case here recorded in which two lines were crossed (for example, lines $A$ and $B$ to produce $D$, also reciprocal crosses between $C$ and $D$ ), the cross was intermediate between the parent lines in the proportion of male-producers. In the one case of reciprocal crosses recorded, the reciprocals were unequal; each was nearer the line that furnished the female parent. Unfortunately, only one of these reciprocals was tested further, so it is not known whether this inequality of the reciprocal crosses disappeared, as was the case with viability, in the subsequent parthenogenetic lines.

When a parthenogenetic line was inbred, the parthenogenetic line derived from its fertilized eggs usually yielded about the same proportion of male-producers as did the parent line. That this was not necessarily the case, however, was shown when two lines were reared from the same lot of inbred eggs. Thus, in $(C \times D) \times(C \times D)$, the line bred from a low viability family of eggs included 37 per cent of male-producers, while the line from a high viability parent yielded only 20.5 per cent. This was not due to the conceivable fact that one line was bred only during a period of many male-producers, the other only during a period of few male-producers; for when these two lines were inbred, and their descendants inbred several times in succession, the 37 per cent series maintained, with one exception, a proportion of male-producers about 35 per cent $\left(L_{1}\right.$ to $\left.L_{4}\right)$, while the 
20 per cent series, with one exception, yielded less than 21 per cent $\left(H_{1}\right.$ to $L_{1}$ from $H$ and $H_{1}$ from $\left.H\right)$. Thus, in $(C \times D) \times$ $(C \times D)$, selection for viability of fertilized eggs was accompanied by a differentiation with respect to the proportion of male-producers such that the least viable eggs yielded the parthenogenetic line with the most male-producers. Precisely the same result appeared in $L_{4}$, where selection for low viability produced a parthenogenetic line with 37.5 per cent of male-producers, while the high viability eggs gave rise to a line with only 13.6 per cent of male producers.

One can not safely generalize, however, and say that a high percentage of male-producers is associated with low viability of fertilized eggs; for in $\mathrm{H}_{3}$ a similar selection for viability of eggs was made, without, as figure 2 shows, any appreciable effect on the percentage of male-producers in the descendent parthenogenetic lines.

\section{INTERPRETATION OF RESULTS}

Viability of fertilized eggs appears to be dependent on segregating factors or genes. Otherwise, two eggs from the same source could not give rise to parthenogenetic lines whose fertilized eggs differ markedly in viability. Selection for viability was effective in a hybrid (heterozygous) lot of eggs because of this segregation.

Since a single selection produced the maximum effect on viability, since this effect was not augmented by subsequent selection, it appears probable that but few genes are concerned with viability. The eggs of the first selected families must have been practically homozygous, or subsequent selection would have augmented the effect. Had the genes affecting viability been numerous, the chance of selecting a completely homozygous egg the first time would have been quite small. I hesitate to suggest that a single pair of genes is involved; but it is quite possible that only one of the elements of viability discussed in a previous section has been studied here, and that the irregularities noted are but the effect of external conditions. 
That inbreeding coupled with selection had produced practically homozygous eggs is further indicated by the negative results of selection in $L_{4}$ and $H_{3}$. Selection for high and low viability within each of these lots of eggs was without effect, as would be expected if the parthenogenetic lines producing the eggs were homozygous with respect to viability.

The greater viability in eggs produced by crossing two lines, as compared with the inbred eggs produced by the same lines, may be the result of increased vigor due to heterozygosis. I have already shown (Shull '12 b) that inbreeding results in decrease of vigor in Hydatina, and Whitney ('12), following a single experiment of mine, has proven that crossing increases vigor. It seems probable that the fact that the reciprocal crosses between $C$ and $D$ and between $L_{2}$ and $H_{2}$ show an average viability plainly in excess of the average viability of the inbred eggs of the same lines, is merely another example of the increase of vigor due to heterozygosis. Which of the several possible elements contributing to viability is affected by heterozygosis can not be determined.

The inequality of the reciprocal crosses with respect to viability of eggs is discussed in a separate section.

Variability in the duration of the fertilized egg stage is not so certainly explainable because the experiments in which marked differences in this variability appeared were few. All of the results of the experiments here described accord fairly well with the assumption that this variability is dependent on a single pair of genes, and that low variability of hatching time is dominant over high variability. Because of the small number of tests obtained, this interpretation may well be incorrect.

The inequality of the reciprocal crosses $C \times D$ and $D \times C$, together with the equality of the inbred and of the crossed eggs obtained from them, is discussed in another section, in connection with the inequality of reciprocal crosses with respect to viability of eggs.

The sex-ratio, or its equivalent, the percentage of male-producing females, behaves as if dependent on a number of genes; but it is difficult to formulate a general statement. In the experi- 
ments described in this paper, the only two parthenogenetic lines $(C \times D$ and $D \times C)$ that were derived from crosses between other lines, were intermediate between their parents in respect to the sex-ratio. This is what would be expected if the sexratio were dependent on a number of genes. But in a previous paper (Shull '11) I described a case in which a cross gave a much higher proportion of male-producers than either of its parent lines. There is a bare possibility that the two lines crossed in this earlier experiment were old; that their percentage of male-producers had been reduced by long continued parthenogenesis, as I have shown (Shull '12 a) to be a not infrequent occurrence; and that when these lines were young their sex-ratios were so high as to have made the $F_{1}$ which was later obtained by crossing, and which was itself a young line, actually intermediate between them. This possibility was discussed in the earlier paper, but the view taken that it was probably not the correct explanation. If my earlier supposition was well grounded, there is still no simple explanation for the inheritance of the proportion of male-producers.

The assumption of numerous genes for the sex-ratio would harmonize with the fact that inbreeding usually does not change the sex-ratio in the resulting parthenogenetic line. Repeated inbreeding showed little alteration in the sex-ratio. Since but one or two eggs were selected from each lot to breed parthenogenetic lines, the chances were many to one that these would be similar to their parent line. The few exceptions, such as the low percentage of male-producers in the high viability line in $L_{4}\left(13.6^{\circ}\right)$, and the high percentage in $H_{1}$ from $H(35.8)$, may be regarded as due to selecting the extremes for parents, or, which seems to me more probable, to the fact that the lines were reared only a few generations during a period of few male-producers in the former line, and through a period of many male-producers in the latter line. 


\section{NUCLEUS AND CYTOPLASM IN HEREDITY}

Unequal reciprocal hybrids are not uncommon both in animals and in plants. Some of them are due to sex-limited inheritance, and have received an explanation that is at least plausible, involving the accessory chromosome. In Oenothera the reciprocals may resemble the mother most in some crosses, and resemble the father ${ }^{2}$ most in other crosses; or may be more like the father in some characters, more like the mother in others; these cases must have a special explanation. In some cases, as echinoderms (Baltzer '10), the inequality seems to be due to the elimination of chromosomes in one of the reciprocals. But there remain a number of cases which apparently belong to none of these categories. A few of these have been collected and discussed by Jones ('12), who himself reports unequal reciprocals in Digitalis. Pearl ('10) obtained a case in fowls very similar to that which I here report in Hydatina; the 'hatching quality' of the eggs was unequal in the two reciprocals. ${ }^{3}$ He suggested that the greater infertility of the one reciprocal might be due to unfavorable action of the secretions of the oviduct on the sperm in that particular cross, but obviously unfavorable action by the egg itself would bring about the same result. Toyama ('12) has obtained unequal reciprocals in the silkworm.

All cases in which the reciprocals are nearer the female parent, unless having some other obvious explanation, might be used as evidence that the cytoplasm is a partial bearer of the hereditary qualities, and some of the cases found have been so interpreted. Certain echinoderm crosses, not necessarily reciprocals, in which the zygote possessed purely maternal larval characters, have received the same explanation. Unfortunately, in some of the most striking cases, the hybrids could not be bred further, owing to infertility, or to the fact that they never reached maturity. Hydatina is particularly valuable in this regard, because

${ }^{2}$ Since this paper went to press Professor Goldschmidt has explained certain patrocline Oenothera hybrids as due to the degeneration of the maternal chromosomes in the fertilized ovum.

3 Dr. Pearl states that the inequality of the reciprocal hybrids was diminished in the next generation. 
the reciprocals were quite easily reared. The results obtained from Hydatina are stated in a preceding section of this paper. When the unequal reciprocals were inbred, and reciprocally crossed, it was found that all traces of the supposed influence of the cytoplasm of the egg had disappeared. The inequality lasted only during the egg stage, and ceased when the eggs gave rise to parthenogenetic lines that could be compared.

In this case it seems necessary to regard the cytoplasm as. part of the environment of the zygote. When new cytoplasm had been manufactured under the influence of the combined nuclei of the two lines, this cytoplasm was approximately equal in the two reciprocal lines.

\section{SUMMARY}

The fertilized eggs of Hydatina senta, unlike the parthenogenetic eggs, do not all hatch. The proportion hatching in various lots of eggs has varied from zero to seventy per cent. The capacity for hatching I have called the 'viability' of the eggs. Some of the factors apparently governing the viability of the eggs are discussed in an early part of this paper.

The viability of eggs produced by inbreeding males and females of the same parthenogenetic line is characteristic of the line producing them. One line produced eggs, none of which hatched; another line produced eggs of which 5 per cent were viable; another showed 40 per cent of viability, and so on.

The viability of the eggs is inherited. When a line whose inbred eggs possessed a viability of 5 per cent was reciprocally crossed with another line with 45 per cent of viable eggs, the reciprocal hybrid lots of eggs were unequal in viability. Each reciprocal was more nearly like the inbred eggs of the maternal line. This result was obtained in two distinct pairs of reciprocal crosses.

The age of fertilized eggs at hatching varies greatly. One egg I have observed hatched in four days after laying; two weeks is a more common age; while many eggs doubtless never hatch. The degree of uniformity of the duration of the egg stage is a characteristic of the line producing the eggs. The inbred eggs of one line practically finished hatching ( 45 per cent were viable) 
within a period of two weeks; in another line, the hatching was spread nearly uniformly over a period of four weeks or more. This variability of the duration of the egg stage may be measured by the standard deviation. In the first of the two lines just mentioned, the standard deviation of the hatching time was low; in the second, the standard deviation was high.

The variability of the duration of the egg stage is inherited. When a line whose inbred eggs showed great variability (high standard deviation) of the hatching time was reciprocally crossed with a line showing small variability (low standard deviation) of the hatching time, the reciprocal hybrid lots of eggs were intermediate between the parents in variability, but were unequal. Each. lot was more nearly like the inbred eggs of its maternal line.

The same pair of reciprocal hybrids were unequal both in viability and in variability of hatching time. This inequality was not permanent, however; that is, it lasted only during the egg stage. For when a parthenogenetic line was derived from each lot of eggs, and these two 'reciprocal' lines were inbred and reciprocally crossed, the inequality observed in the former lots of eggs did not appear in the eggs of the reciprocal lines. In the latter lots of eggs, the inbred lots were approximately equal, and the reciprocal hybrids were approximately equal.

The inequality of the reciprocal hybrids in the egg stage can not be interpreted as due to the influence of the cytoplasm in heredity. The cytoplasm must rather be regarded as part of the environment.

In the inheritance of viability of the eggs of Hydatina, segregation occurs in the production of the gametes. For this reason, selection for high and low viability within a hybrid (heterozygous) lot of eggs was plainly effective. But the whole effect was obtained by the first selection, this effect not being increased by subsequent selections. I conclude from the rapidity with which the maximum effect of selection was reached, that the number of segregating units concerned with viability of eggs is small.

After several successive inbreedings from a line that was plainly heterozyggous with respect to viability, selection for high and 
low viability was wholly ineffective. From this I judge that inbreeding (and selection?) had produced a line homozygous with respect to viability.

The sex ratio (proportion of male-producing females) is inherited. In two series of parthenogenetic lines, each line of which was produced by inbreeding from the preceding line, the sex ratio remained nearly constant. In one series the ratio was about 35 per cent of male-producers, in the other series about 20 per cent. The effect of crossing on the sex ratio is not clear, as the labor of rearing several parthenogenetic lines prohibits the acquiring of sufficient data. The experiments described in this paper are in fair accord with the assumption that numerous factors, or genes, unite in producing the sex ratio. A possible method of harmonizing this assumption with contradictory results previously published is discussed above.

\section{BIBLIOGRAPHY}

Baltzer, F. 1910 Utber die Beziehungen zwischen dem Chromatin und der Entwickelung und Vererbungsrichtung bei Echinodermenbastarden. Arch. f. Zellforsch., Bd. 5, pp. 497-621.

Jones, W. N. 1912 Species hybrids of Digitalis. Journ. Genet., vol. 2, no. 2, June, pp. 71-78.

Pearl, R. 1910 Poultry notes. Maine Agl. Exp. Sta., Bull. 179, May.

Shuld, A. F. 1911 Studies in the life cycle of Hydatina senta. II. The rôle of temperature, of the chemical composition of the medium, and of internal factors upon the ratio of parthenogenetic to sexual forms. Jour. Exp. Zoöl., vol. 10, no. 2, February, pp. 117-166.

1912 a III. Internal factors influencing the proportion' of male-producers. Ibid., vol. 12, no. 2, February, pp. 283-317.

$1912 \mathrm{~b}$ The influence of inbreeding on vigor in Hydatina senta. Biol. Bull., vol. 24, no. 1, December, pp. 1-13.

Toyama, K. 1912 On certain characteristics of the silkworm which are apparently non-Mendelian. Biol. Centralb., vol. 32 , no. 10, October 20, pp. 593-607.

Whitney, D. D. 1912 Reinvigoration produced by cross fertilization in Hydatina senta. Jour. Exp. Zoöl., vol. 12, no. 3, April, pp. 337-362. 